\title{
ENGINEERING SOILS MAP OF MIAMI COUNTY, INDIANA
}

SEPTEMBER 1972 - NUMBER 35

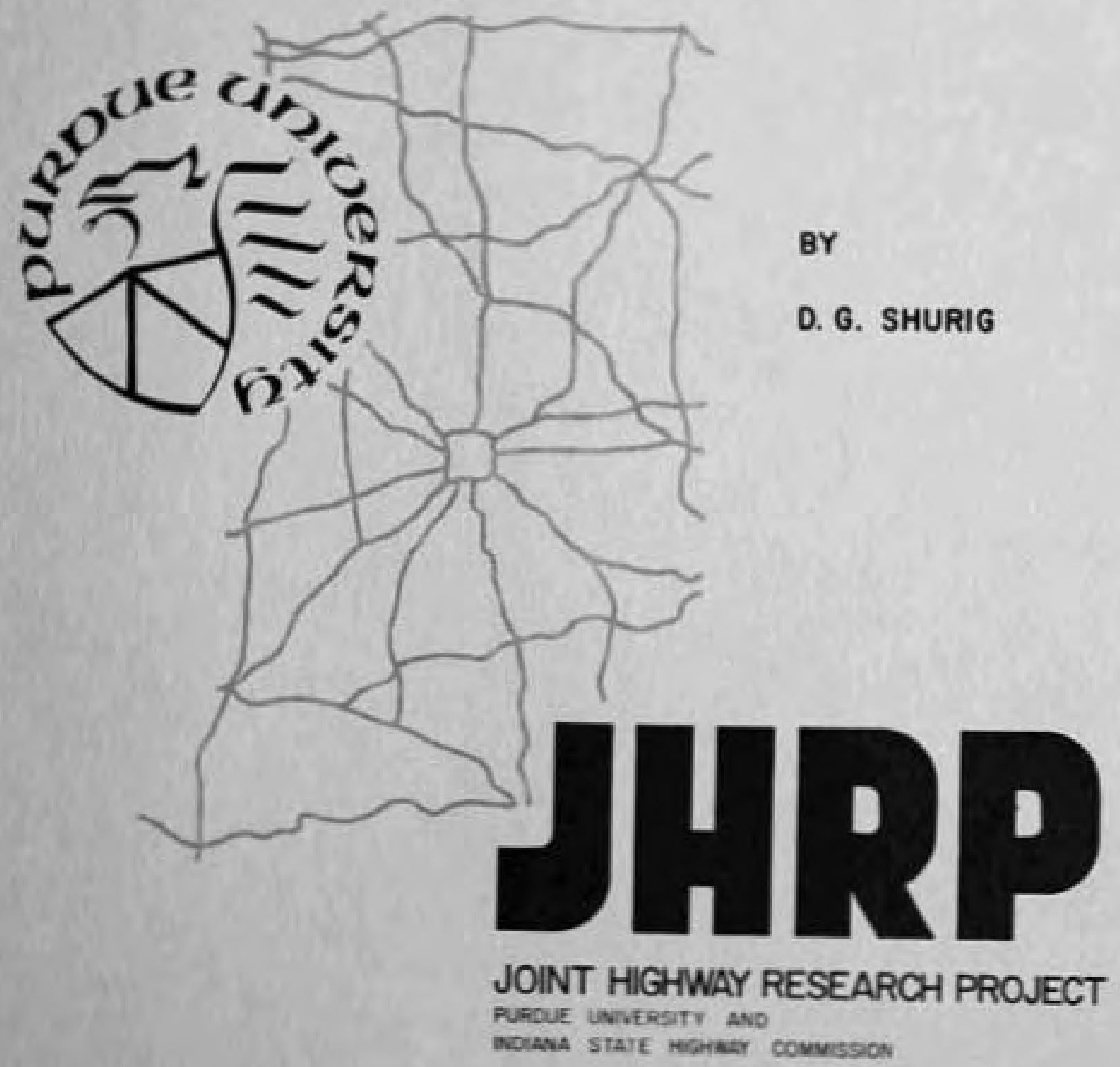


Final Report

ENGINEERING SOILS MAP OF MIAMI COUNTY, INDIANA

To: J. F. McLaughlin, Director

Joint Highway Research Project

FROM: H. L. Michael, Associate Director Joint Highway Research Project
September 7, 1972

File: $1-5-2-53$

Project: C-36-51B

The attached report, entitled "Engineering Soils Map of Miami County, Indiana", completes a portion of the project concerned with development of county engineering soils map of the state of Indiana. This is the $53 \mathrm{rd}$ report in the series. The report was prepared by Prof. D. G. Shurig, Research Associate, Joint Highway Research Project.

The soils mapping of Miami County was done primarily by airphoto interpretation. Generalized soil profiles of the major soil for each 1 and form are presented on the engineering soils map. An ozalid print of the Engineering Soils Map of Miami County is included in the report.

Respectfully submitted,

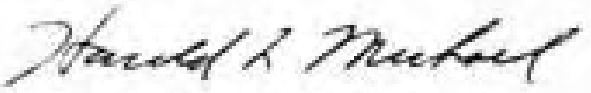

Harold L. Michael

Associate Director

HLM:ms

cC: W.L. Dolch

R.L. Eskew

W.H. Goetz

M.J. Gutzwiller

G.K. Hallock

R.H. Harre11
M. L. Hayes

C. W. Love11

G. W. Marks

R. D. Miles

J. W. Miller

G. T. Satterly
C. F. Scholer

M. B. Scott

J. A. Spooner

N. W. Steinkamp

H. R. J. Walsh

E. J. Yoder 


\section{Final Report}

ENCINEERING SOILS MAP OF MIAMI COUNTY, INDIANA

by

D. G. Shurig

Research Associate

Joint Highway Research Project

Project No.: C-36-51B

File No.: 1-5-2-53

Conducted By

Joint Highway Research Project

Engineering Experiment Station

Purdue University

In Cooperation with

Indiana State Highway Commission

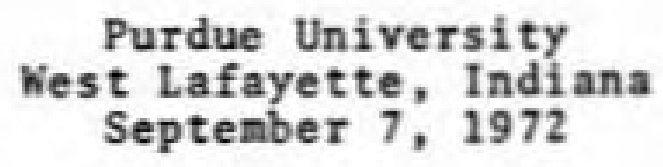


Digitized by the Internet Archive in 2011 with funding from

LYRASIS members and Sloan Foundation; Indiana Department of Transportation

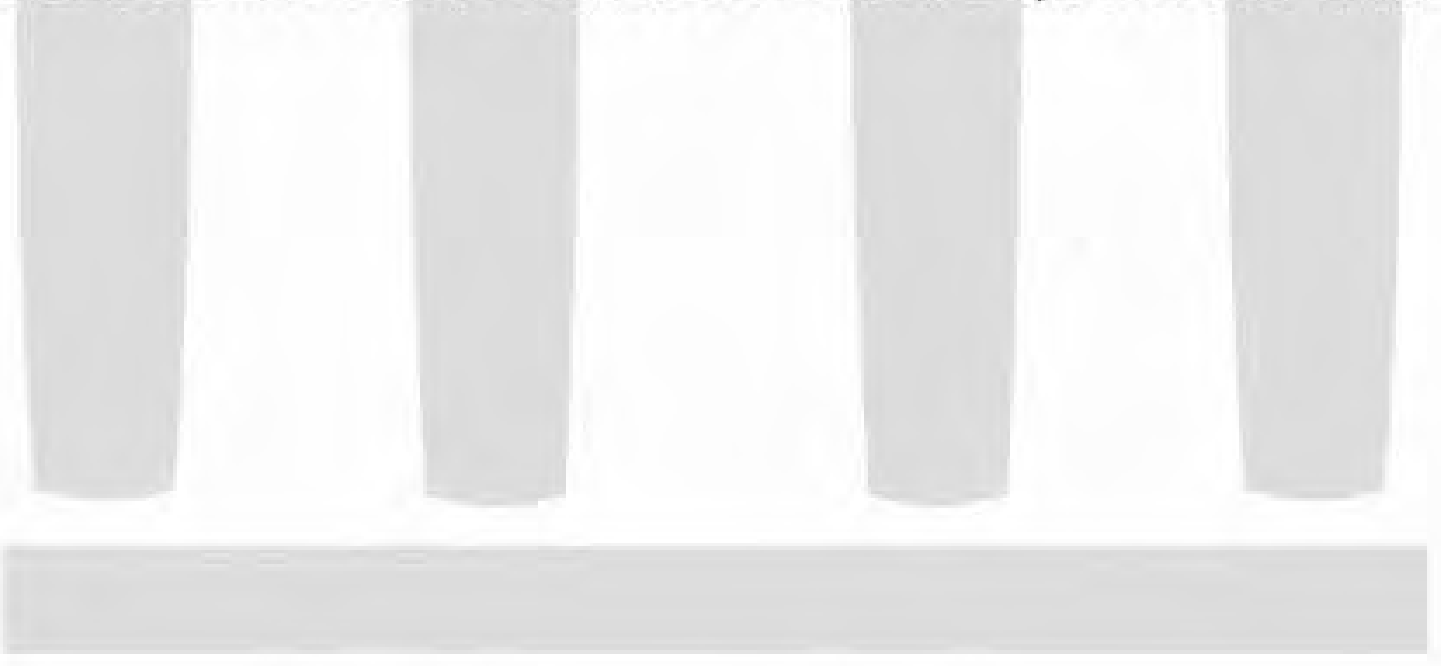

http://www.archive.org/details/engineeringsoils7235shur 
ENGINEERING SOILS MAP

OF

MIAMI COUNTY, INDIANA

\section{INTRODUCTION}

Development of an engineering soils map of Miami County (in back cover pocket of this report) was the primary objective of this project. The purpose of the following report is to supplement the information appearing on the enqineering soils map.

An important source of information used in this mapping project was Geological Survey Bulletin No. 8, "The Geology of Miami County, Indiana", by Thornbury and Deane (1). Routine airphoto interpretation techniques were used to outline land form parent material and engineering soils boundaries. A one day field reconnaissance was also made. The only pedological survey available at the time of this report was a 1927, "Soil Survey of Miami County, Indiana" (2) and a preliminary type soil association map (3).

The photographs used were $9 \times 9$ in. contact prints at an a approximate scale of 1:20,000. Date of photography was 1941 .

The final land form and parent material boundaries were graphically reduced to produce the engineering soils map. Symbols were used to delineate the parent materials (grouped according to land form and origin). Textural symbols were then superimposed to indicate the relative composition of the parent materials. The map also includes a set of soil profiles which indicate the general soil profiles of topographically high and low sites in each parent material area. Each profile shows the general range in depth and texture (ISHC textures) of each soil horizon.

\section{DESCRIPTION OF AREA}

Location and Population Data

Miami County is located in north-central Indiana - see Figure 1. Peru, the county seat, is about $70 \mathrm{miles}$ north-northeast of Indianapolis. 


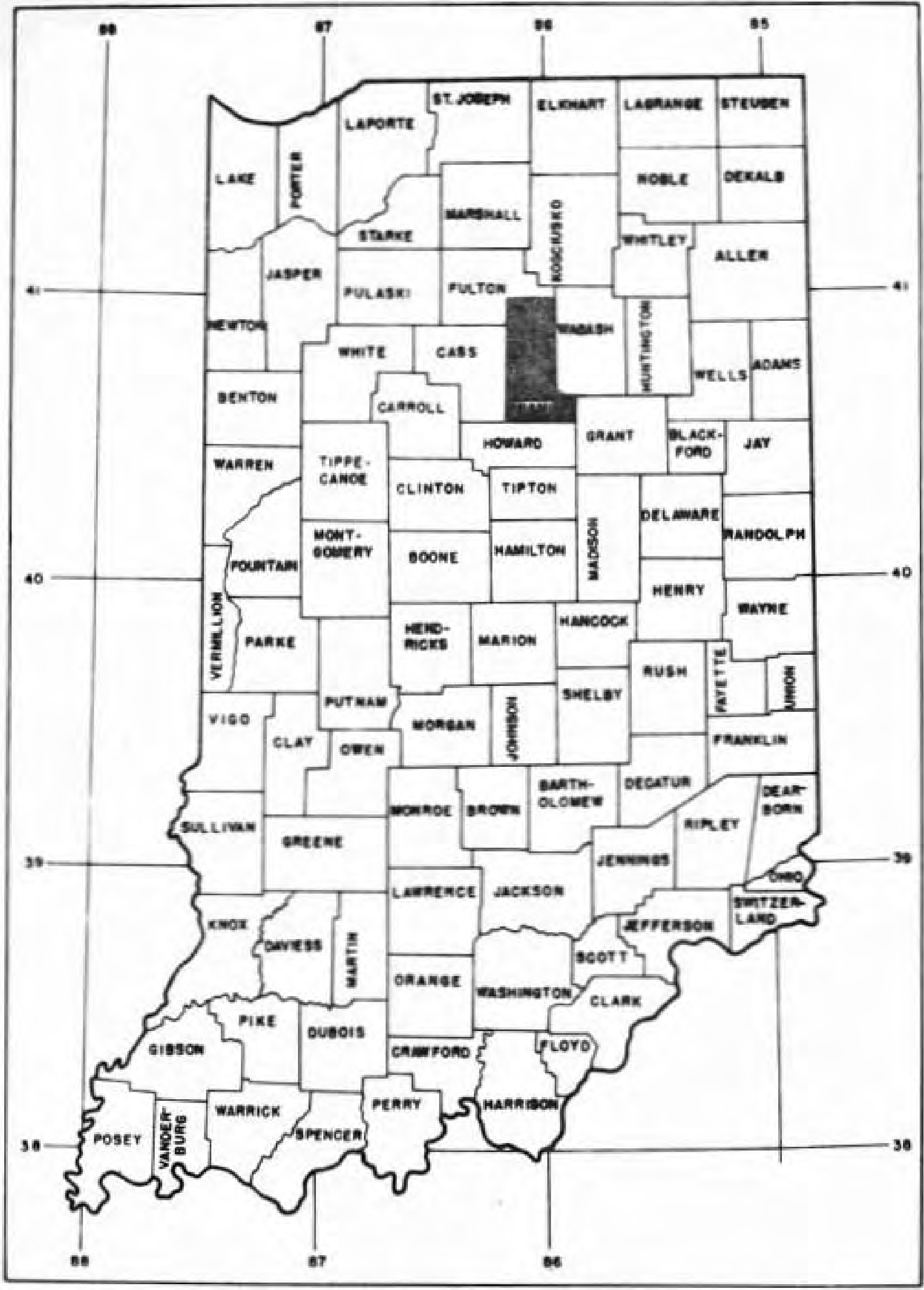

FIG. I. LOCATION MAP OF MIAMI COUNTY 
Miami County is bounded on the west by Cass and Fulton Counties, on the north by Fulton County, on the east by wabash and Grant counties, and on the south by Howard County.

The county is 30 miles long, north-south, and 12 miles wide except in the extreme southern part where it is 16 miles wide in the east-west direction. It has an area of 384 square miles.

Some significant population data for Miami County is shown below - it is from the 1970 Census (4).

\begin{tabular}{|c|c|c|c|}
\hline $\begin{array}{c}\text { Population } \\
\text { Cities and Towns }\end{array}$ & $\begin{array}{c}\text { Population } \\
\underline{1970}\end{array}$ & $\begin{array}{c}\text { Population } \\
1960\end{array}$ & $\begin{array}{c}\text { Population } \\
\text { Change ' } 60-' 70\end{array}$ \\
\hline $\begin{array}{l}\text { Amboy } \\
\text { Bunker Hill } \\
\text { Converse } \\
\text { Denver } \\
\text { Macy } \\
\text { North Grove } \\
\text { Peru }\end{array}$ & $\begin{array}{r}473 \\
956 \\
1,163 \\
566 \\
273 \\
107 \\
14,139\end{array}$ & $\begin{array}{r}466 \\
1,049 \\
1,044 \\
565 \\
328 \\
127 \\
14,453\end{array}$ & $\begin{array}{r}6.1 \\
-8.9 \\
11.4 \\
0.2 \\
-16.8 \\
-15.7 \\
-2.2\end{array}$ \\
\hline $\begin{array}{l}\text { Cities \& Towns } \\
\text { Rural Areas } \\
\text { County Total }\end{array}$ & $\begin{array}{l}17,677 \\
21,569 \\
39,246\end{array}$ & $\begin{array}{l}18,012 \\
19,988 \\
38,000\end{array}$ & $\begin{array}{r}-1.9 \\
7.9 \\
3.3\end{array}$ \\
\hline
\end{tabular}

DRAINAGE FEATURES

Figure 2 shows a drainage map of Miami County (5). Miami County is in the Wabash drainage basin of the State. Major tributary streans to the Wabash River, flowing from east to west across the center of the state, include the Eel river in the north and the Mississinewa River in the south.

The U.S. Army Corps of Engineers has constructed a dam and reservoir on the Mississinewa River in Miami County. Location of the dam and the extent of the flood pool are shown on the engineering soils map. Detailed information circulars are available on the reservoir $(6)$.

The following drainage information is quoted from the "Atlas of County Drainage Maps of Indiana - Miami County" (5).

"Miami County lies wholly within the Wabash drainage basin of the state (3). A main subdivision is the Eel River basin.

"The Wabash Valley acted as a glacial sluiceway and is rather wide in places. Streams are widely 


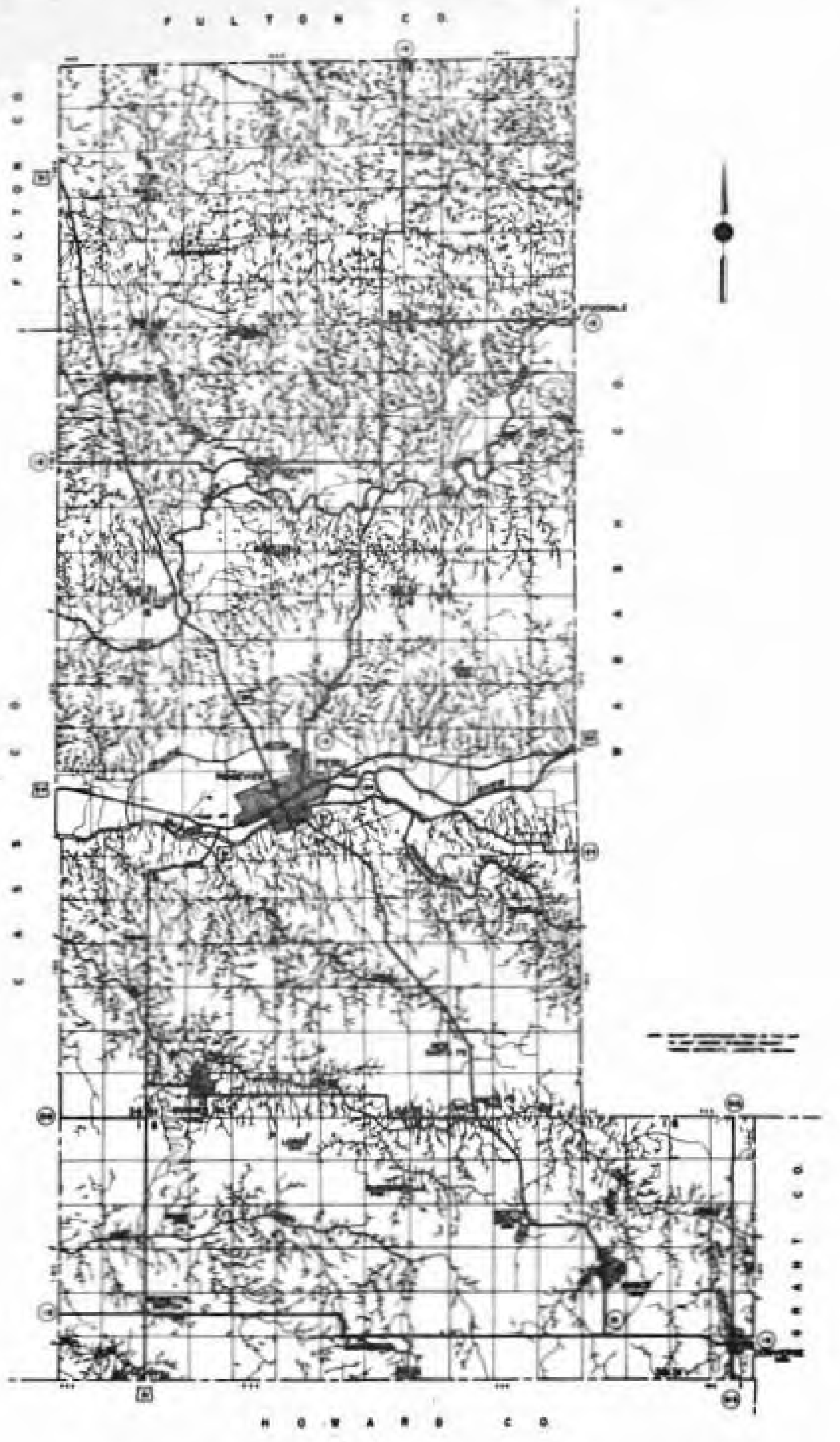


spaced in the southern part. There is little development of natural drainageways in the southern part of the county. Natural drainage is best developed in the uplands adjacent to the Wabash Valley. The area between the Wabash and Eel rivers has fair natural drainage. The northern part is well drained due to a more rolling terrain, although several nearly flat areas do exist. Little Pipe Creek contacts rock near Peru. Headuater streams of Big Pipe Creek have tortuous courses. Crests of sections of noraines define watershed divides in the county. Some stream courses and some stream deflections are affected, at least partially, by the presence of the moraines. Increased densities of drainage patterns in the northern part occur in a moranic area. The course of Eel River appears to be controlled by the Packerton moraine. The Eel River Valley is fairly wide but its valley walls are not as abrupt as those of the Wabash valley; it is, however, rather deeply entrenched. Deer Creek crosses a morainic area. The general course of Big Pipe Creek nearly parallels the Union City moraine; its headwater streams are apparently influenced by the moraine because of their northerly direction of flow. Deer creek flows in a westerly direction; its headwater streams flow northerly. In general, tributaries of the Wabash River from the north are small. Eel River flows along the south side of the Packerton moraine. Its tributaries show deflections. Actual flood plains of the Wabash and Mississinewa river valleys are narrow in places. Tippecanoe tributaries drain the northwest corner.

"There are no natural lakes in the county. Ponds of various origins exist in the several sections of the area.

"Ditches have been constructed in the nearly level and low-lying areas to improve sluggish drainage conditions. Streans have been dredged; e.g., Deer Creek in the southern part of the county. Ground water levels have been lowered in many places.

" Stream gaging stations are located on the Wabash River at Peru and on the Mississinewa River at Peoria (12). The drainage area of the Wabash River above Peru is about 2,810 square miles (11). The Mississinewa River has a drainage area of about 890 square miles (11):

GLACIAL GEOLOGY

Thornbury and Deane published a detailed report "The Geology of Miami County, Indiana" in 1955. Information pertaining to engineering soils is sumarized below. 
Ice covered Miami County during at least three glacial ages. Kansan, Illinoian and Wisconsin. The deepest stream cuts, however, expose only Wisconsin drift.

The glacial drift cover ranges from none, at bedrock exposures in some recent stream valleys, to over 450 feet where the Packerton moraine crosses Meteavalley - a preglacial valley see Figure $3(7)$. The preglacial and interglacial Teays River was the main stream across the county. At a few places parts of the buried valley are about 320 feet below surface. The average thickness of drift along this preglacial stream and the present Wabash flood plain, however is 240 feet. In general, drift thickness over the county is 125 feet. (1)

The Wisconsin Age of glaciation consisted of two subages, Tazewel1 the oldest and Cary the youngest. During the Tazewell subage the ice front moved back and forth across the county several times. This flucuation is indicated by several layers of outwash and weathered till exposed in some of the deeper stream cuts.

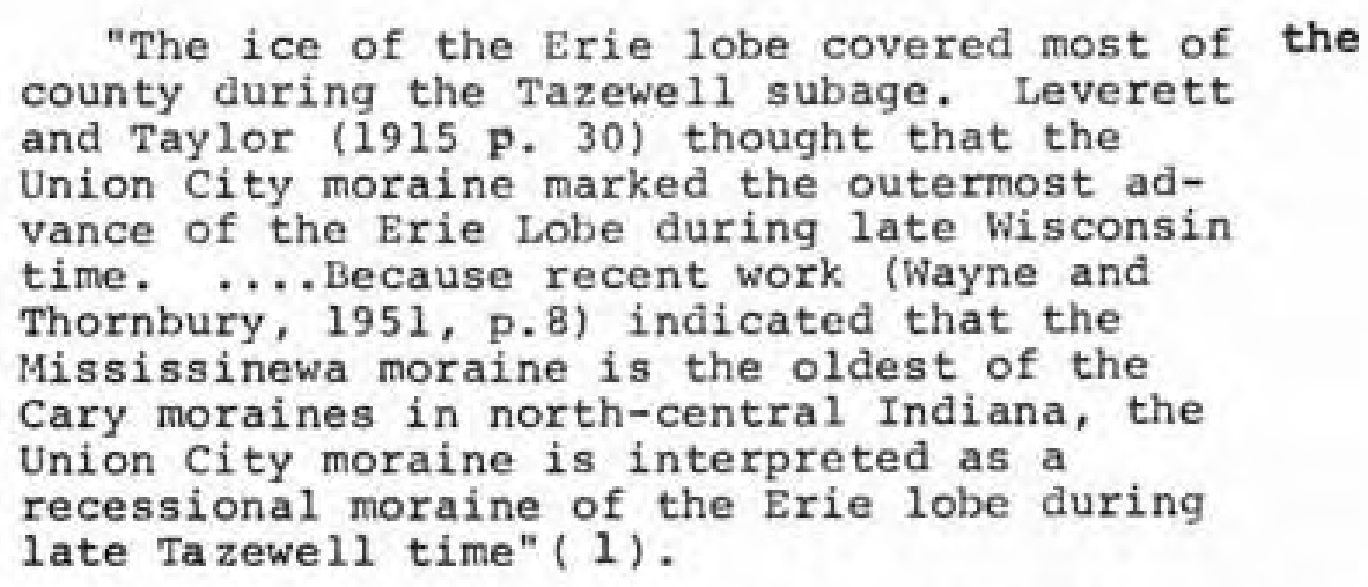

After Tazewe11 time there was an interglacial period of 10,000 to 12,000 years. After this, the Cary subage began and it is thought that the farthest advance of the Erie Lobe, in Cary time, was to the Mississenewa ridge moraine.

The Packerton moraine in north-central Indiana has been considered by most persons, who have studied it, to be a large interlobate moraine between the Saginaw and Erie lobes. Wayne and Thornbury have reason to believe that part of the Packerton moraine south of Disko was built by the Erie lobe and the part north of Disko by the Saginaw lobe (1). 


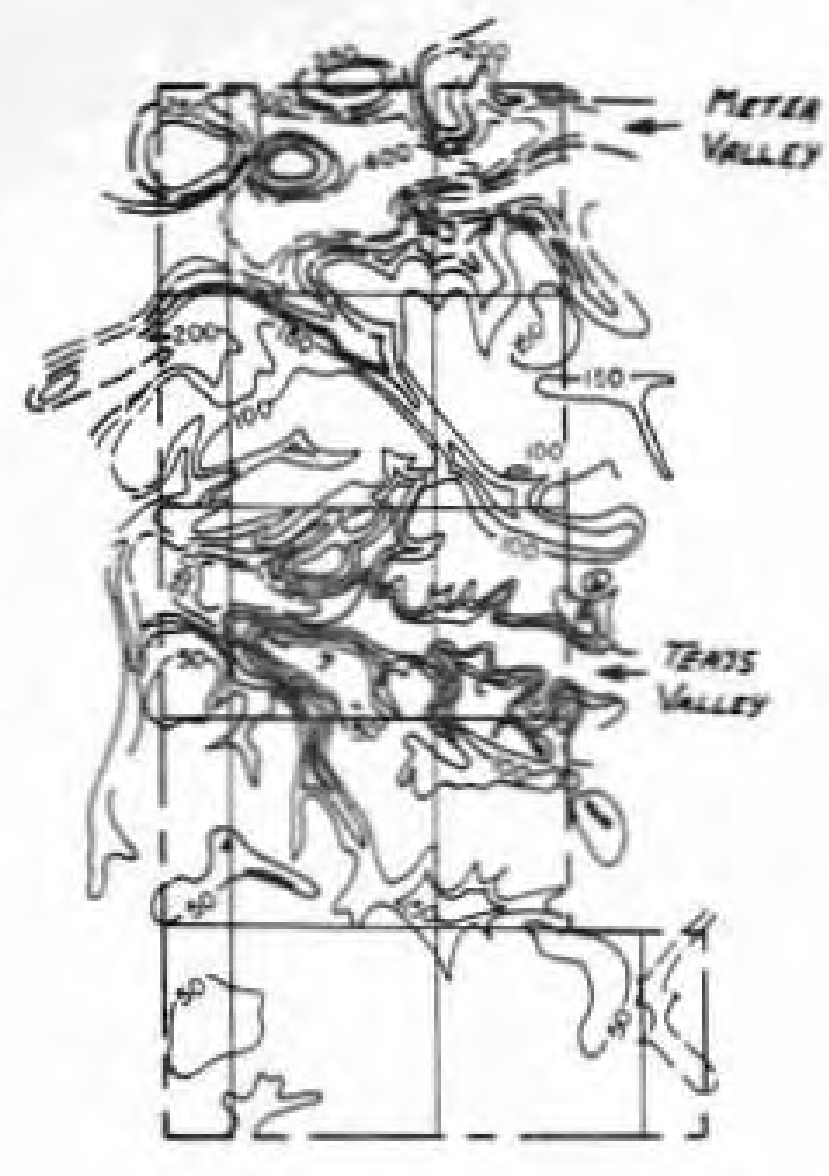

GLACIAL DRIFT THICKNESS (WAYNE-1956)

$50 \mathrm{Ft}$. Contour Interval

- 1 Bedrock Outcrops

* Quorry

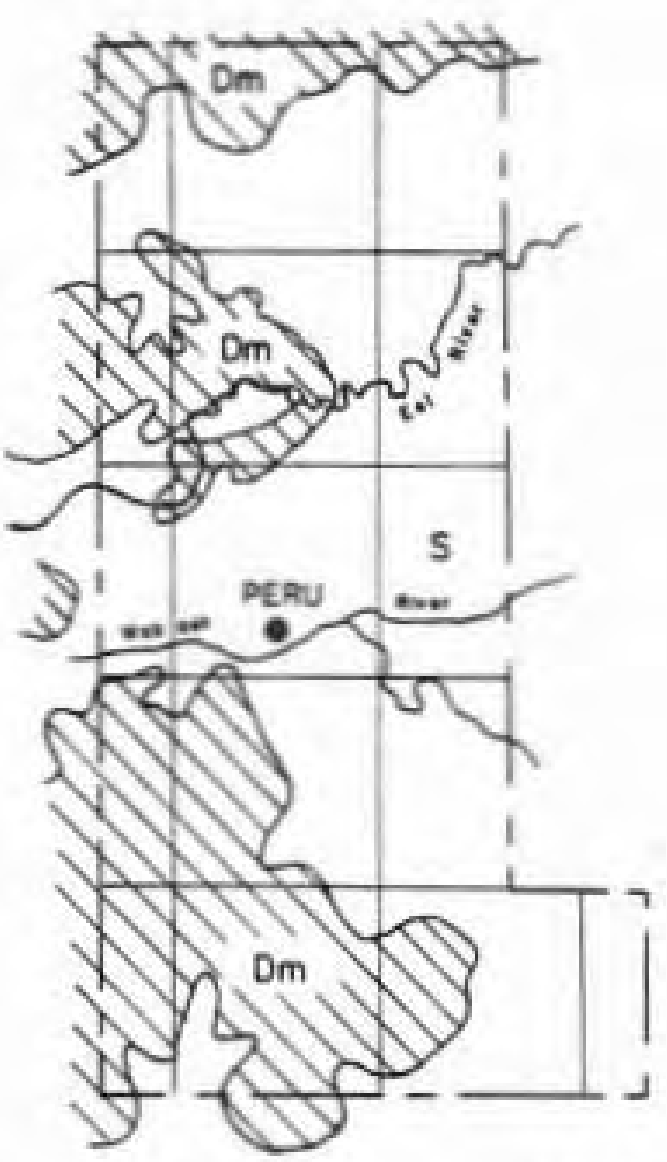

BEOROCK GEOLOGY (PATTON-1956)

S Silurion

Ls., Dolo., and Sh.

Dm Middle Devonion

L5., Dolo., and Ss.

FIG. 3. 
The Wabash Valley has a rather unique glacial history. The valley has three levels: an upper terrace, the Mississinewa terrace, a lower terrace called the Maumee terrace and a third and lowest level which is the recent flood plain. The upper Mississinewa terrace was formed in the late Tazewe11 subage and the early Cary subage. The lower Maunee terrace was forned in the late Cary subage when glacial lake Maunee broke through its ridge moraine dam - near the present City of Fort Wayne. The relatively clear lake water was mostly degradational and cut the newer and lower Maume terrace. The two terrace levels can be traced all the way to the mouth of the Wabash River.

\section{BEDROCK GEOLOGY}

"The rocks that crop out in Miami County belong to the Silurian and Devonian systems. Bedrock is exposed at 31 places along the Wabash River and its tributaries, Little and Big Pipe Creeks, and the Mississinewa River (pl. 1). Outcrops are small both laterally and vertically. The shales, limestones, and dolomites that constitute the bedrock dip to the northwest at a rate of a few feet to the mile, except in the Logansport structural sag between Peru and Logansport, in Cass County, where the dip is somewhat steeper.

"Silurian rocks in Miami County consist of the Mississinewa shale, the Liston Creek formation, associated bioherms (see below) of Niagaran age, and the Kokono 1 imestone of Cayugan age. The oldest exposed rock, the Mississinewa shale, is underlain by limestones and dolonites, about 200 feet thick, of Niagaran age (Middle Silurian).

"Patton (1949, p.11) stated that the Mississinewa at most exposures is blue-gray, argillaceous, dolomitic, silty, massive limestone which has conchoidal fracture, but that in places it is gray calcareous shale.

"Evidence of the presence of the Mississinewa formation was found at one place in Miami County. Along Prairie Ditch about 1 mile northwest of Peru. Patton (1949, P.12) described the Liston Creek formation as a gray, thin-bedded, dolomitic, cherty limestone which contains intercalated beds of chert. The upper part is more cherty than the lower. The formation ranges from a few feet to as much as 60 feet in thickness. The maximum exposed thickness in Miami County is 28 feet. mainly along the Mississinewa and Wabash Rivers and Big Pipe Creek. 
"The exoding melt-water and recent waters flowing down the Wabash, Mississinewa Rivers and Little Pipe Creek uncovered many Silurian bioherms (reef rock formations). The resistant dolomite of these reefs was more difficult to erode than inter-reef rock and, in some places, unconsolidated drift - thus the old exhumed reefs became islands in the sluiceways. Cumings and Shrock applied the name klint (p1.klintar) to the exhumed remnant of an ancient bioherm. The Maunee terrace and the present flood plain are studded with klintar, but only a few stand above the higher Mississinewa terrace - see the attached soils map.

"The small dome-like structures that are found in the Silurian rocks of northern Indiana are called bioherms (organic mounds) or, less accurately, reefs. They are of Niagaran age and are associated intimately with the Mississinewa and the Liston Creek formations. The reefs are, in general, domeshaped masses of dolomitic material which have massive, unstratified cores composed in part of the remains of stromatoporoids, corals, bryozoa, and algae. Because corals constitute only a small part of the total mass, the name coral reef, which so often is applied to them, is not especially appropriate (Cumings and Shrock, 1928b,p.599)

"The rock which composes the reef core is hard, gray to pink, ragged, porous dolomite that contains many pockets of calcite. Fossils that are found within the core are poorly preserved. The reef core is characterized by silickensides, many of which are inclined at angles of 45 to 65 degrees. Stylotites are developed along the slickensided surfaces and bedding planes and are the result of intraformational solution under the static pressure of the overlying rock after the solidification of the rock (Cumings and Shrock, 1927,p.78). The visible parts of most of the reef cores do not exceed 75 feet in height and 300 feet in diameter. The core rock commonly is more resistant to erosion than is the surrounding rock.

"The inclined beds which enclose the reef constitute the forereef and often are referred to as the flank rock. The flank rock is typically yellowish-gray to pinkish limestone or dolomite. The dips in the forereef may be as much as 65 degrees at or near the reef core and decrease to 3 or 4 degrees or less on the periphery of the bioherm. Faults and slickensides are abundant in the beds of the fore-reef. Within a few hundred feet of the core, the beds of the fore-reef interfinger with normal Mississinewa shale or Liston Creek limestone (Cummings and Shrock, 1928a, p.142-144) (8). 
"Fourteen bioherms are exposed in Miami County (pl.1). See the soils map.

"Patton (1949,p.13) described the Kokomo formation as gray to brown, banded dolomitic limestone, much of which is finely laminated. He observed that near Peru the upper beds are brecciated, crumpled, contorted, faulted, and recemented. The Kokomo limestone ranges from a few feet to as much as 60 feet in thickness. The maximum exposed thickness of the Kokomo in Miami County is $41 / 2$ feet. The Kokomo limestone is exposed at eight places in Miami County (pl.1).

"The Devonian rocks in Miami County are limestones of Hamilton age. Outcrops are confined to the western part of the county along the Wabash River and along Little and Big Pipe Creeks.

"In Miami County these beds consist of white to gray, coarsely crystalline, thin-bedded to massive limestone. Their maximum exposed thickness in the county is $61 / 2$ feet. The limestone is exposed at four places along Big Pipe Creek near the town of Bunker Hill (pl.1)." (1)

\section{CLIMATE}

The nearest weather station to Miami County having a published summary of climatological data is in adjacent wabash County at Wabash, Indiana.

The following page provides consideraple data on the general climate of the area (8) (9). 


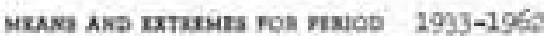

\begin{tabular}{|c|c|c|c|c|c|c|c|c|c|c|c|c|c|c|c|c|c|c|c|c|c|c|}
\hline \multirow[b]{4}{*}{$\begin{array}{l}\frac{1}{2} \\
\frac{5}{2} \\
\frac{1}{2}\end{array}$} & \multicolumn{7}{|c|}{ Temperature ( $\left.{ }^{\circ} \mathrm{F}\right)$} & \multirow{4}{*}{$\begin{array}{l}\text { : } \\
\text { है } \\
\text { है } \\
\frac{8}{8} \\
\frac{8}{2} \\
\frac{8}{2}\end{array}$} & \multicolumn{8}{|c|}{ Pracipilation Totala (lachee) } & \multicolumn{5}{|c|}{ Mean numl et of days } & \multirow[b]{4}{*}{ 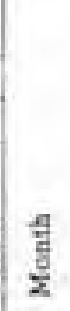 } \\
\hline & \multirow{2}{*}{\multicolumn{3}{|c|}{ Meens }} & \multirow{2}{*}{\multicolumn{4}{|c|}{ Extremes }} & & \multirow[b]{3}{*}{$\frac{g}{2}$} & \multirow{3}{*}{$\frac{\text { है }}{\frac{\vec{d}}{\mathrm{~g}}}$} & \multirow[b]{3}{*}{$\frac{\vec{z}}{2}$} & \multirow{2}{*}{\multicolumn{5}{|c|}{ Bnov, sleet }} & \multirow{3}{*}{$-\begin{array}{l}\frac{f}{4} \\
\frac{g}{0} \\
\frac{6}{8} \\
\frac{8}{2}\end{array}$} & \multicolumn{4}{|c|}{ Temperatures } & \\
\hline & & & & & & & & & & & & & & & & & & \multicolumn{2}{|c|}{ Max. } & \multicolumn{2}{|c|}{ Mis } & \\
\hline & 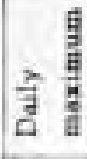 & 为戛 & $\begin{array}{l}\frac{}{3} \\
\frac{3}{2} \\
\frac{g}{2}\end{array}$ & 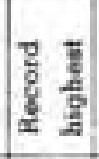 & d & $\begin{array}{ll}\frac{7}{2} & \text { ैㅐ } \\
\frac{8}{2} & \frac{2}{2} \\
\end{array}$ & gु & & & & & $\frac{5}{2}$ & 晋 & हैं & $\frac{\frac{\pi}{2}}{\frac{2}{2}} \frac{\vec{d}}{\mathrm{~d}}$ & है & & $g$ & सै & $\frac{\mathrm{g}}{\mathrm{s}}$ & $\mid \begin{array}{ll}\frac{7}{6} & \frac{5}{6} \\
5 & \frac{5}{6}\end{array}$ & \\
\hline $\begin{array}{l}\text { (a) } \\
\text { Jest. } \\
\text { Pab. } \\
\text { Mar. } \\
\text { Apr. } \\
\text { Moyy } \\
\text { Jone }\end{array}$ & $\begin{array}{c}30 \\
34.9 \\
37.5 \\
46.6 \\
60.5 \\
72.5 \\
82.1\end{array}$ & \begin{tabular}{|c|}
30 \\
18.7 \\
20.3 \\
28.1 \\
38.6 \\
48.8 \\
58.9
\end{tabular} & \begin{tabular}{|c|}
30 \\
36.8 \\
38.9 \\
37.6 \\
49.6 \\
60.6 \\
70.5
\end{tabular} & $\begin{array}{l}30 \\
70 \\
70 \\
82 \\
90 \\
96 \\
106\end{array}$ & $\begin{array}{l}1950 \\
1957 \\
1945 \\
1942 \\
1994 \\
1934\end{array}$ & 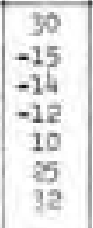 & $\begin{array}{l}1961^{+} \\
1933 \\
1960^{\circ} \\
1957 \\
1954^{+} \\
1956\end{array}$ & $\begin{array}{l}30 \\
1159 \\
1011 \\
860 \\
+65 \\
190 \\
36\end{array}$ & $\begin{array}{l}30 \\
2.46 \\
2.18 \\
2.73 \\
3.49 \\
3.76 \\
4.17\end{array}$ & $\begin{array}{c}30 \\
2.60 \\
2.70 \\
2.39 \\
2.14 \\
2.25 \\
2.70\end{array}$ & $\begin{array}{l}1990 \\
1959 \\
1999 \\
2959 \\
1949 \\
1958\end{array}$ & $\begin{array}{l}30 \\
5.1 \\
3.6 \\
3.2 \\
.4 \\
7 \\
0\end{array}$ & \begin{tabular}{|c|}
30 \\
12.4 \\
14.6 \\
10.2 \\
4.0 \\
$\overline{6}$ \\
0
\end{tabular} & $\begin{array}{l}1999 \\
1962 \\
1925 \\
1962 \\
1947\end{array}$ & $\begin{array}{l}30 \\
9.0 \\
3.0 \\
7.5 \\
4.0 \\
7 \\
0\end{array}$ & $\begin{array}{l}1927 \\
1960 \\
1991 \\
1961^{4} \\
1947\end{array}$ & $\begin{array}{r}10 \\
5 \\
4 \\
7 \\
8 \\
8 \\
7\end{array}$ & \begin{tabular}{|r|}
30 \\
0 \\
0 \\
0 \\
1 \\
1 \\
6
\end{tabular} & $\begin{array}{l}30 \\
12 \\
8 \\
4 \\
0 \\
0 \\
0\end{array}$ & $\begin{array}{l}30 \\
27 \\
35 \\
\frac{25}{9} \\
9 \\
0 \\
0\end{array}$ & $\left|\begin{array}{c|}30 \\
3 \\
0 \\
1 \\
0 \\
0 \\
0\end{array}\right|$ & 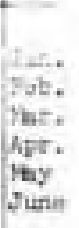 \\
\hline $\begin{array}{l}\text { July } \\
\text { Aug. } \\
\text { Dopt. } \\
\text { Oet. } \\
\text { Nov. } \\
\text { Dec. }\end{array}$ & $\begin{array}{l}86.4 \\
84.6 \\
76.2 \\
66.7 \\
29.5 \\
37.4\end{array}$ & $\begin{array}{l}62.9 \\
98.7 \\
30.9 \\
4.1 \\
31.1 \\
21.5\end{array}$ & $\begin{array}{l}74.7 \\
7.7 \\
63.6 \\
54.4 \\
7.4 \\
2.4\end{array}$ & $\begin{array}{l}103 \\
101 \\
102 \\
70 \\
96 \\
65\end{array}$ & $\begin{array}{l}1936 \\
1974 \\
1939 \\
1949 \\
1950 \\
1946\end{array}$ & $\begin{array}{r}42 \\
40 \\
25 \\
19 \\
-1 \\
-11\end{array}$ & $\begin{array}{l}1947 \\
1962 \\
1942 \\
1960^{\circ} \\
1950 \\
1960\end{array}$ & $\begin{array}{r}6 \\
9 \\
202 \\
350 \\
747 \\
1094\end{array}$ & $\begin{array}{l}3.58 \\
3.74 \\
2.74 \\
2.97 \\
2.72 \\
1.95\end{array}$ & $\begin{array}{l}4.21 \\
3.64 \\
4.29 \\
2.50 \\
3.94 \\
1.51\end{array}$ & $\begin{array}{l}1955 \\
1933 \\
1950 \\
1944 \\
1936 \\
1946\end{array}$ & $\begin{array}{c}0 \\
0 \\
0 \\
7 \\
1.7 \\
5.2\end{array}$ & $\begin{array}{c}0 \\
0 \\
0 \\
7 \\
11.5 \\
15 \cdot 3\end{array}$ & $\begin{array}{l}1962^{\circ} \\
1950 \\
194\end{array}$ & $\begin{array}{c}0 \\
0 \\
0 \\
0.2 \\
11.0 \\
11.0\end{array}$ & $\begin{array}{l}1929 \\
1932 \\
1929\end{array}$ & $\begin{array}{l}7 \\
6 \\
5 \\
5 \\
6 \\
4\end{array}$ & $\begin{array}{l}9 \\
7 \\
3 \\
0 \\
0 \\
0\end{array}$ & $\begin{array}{l}0 \\
0 \\
0 \\
0 \\
2 \\
9\end{array}$ & $\begin{array}{r}0 \\
0 \\
1 \\
6 \\
19 \\
24\end{array}$ & $\begin{array}{l}0 \\
0 \\
0 \\
0 \\
0 \\
2\end{array}$ & 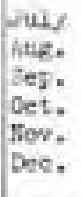 \\
\hline$Y_{\text {mat }}$ & 61.2 & 60.1 & 50.7 & 109 & $\begin{array}{l}\text { July } \\
1936\end{array}$ & -2 & $\begin{array}{l}\text { Dee. } \\
1960\end{array}$ & 6045 & 36.33 & $\begin{array}{l}\operatorname{seg} ; \\
6.29\end{array}$ & 1950 & 22.4 & 15.3 & $\begin{array}{l}\text { Dee: } \\
194 \text {. }\end{array}$ & 11.0 & 190: & 72 & 26 & 35 & 236 & 61 & Yeas \\
\hline
\end{tabular}

(i) Avernge leagth of record, yesra.

T. Trace, as amount too small to measure
+ Also on earlier dates, mosthe, or years.

- Leas tbss ose hall.

*. Base $65^{\circ} \mathrm{F}$

ctrinez of water, Drutu

Vobash is located in Wabala County, swprodisately in the center of the nurthers hatf of Initents. Hovy lays are plenanst in the spring and fnll, hovever, tagperstutres axoeod go degrees on nbout

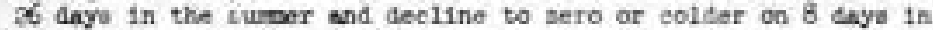
the vister. Fainfall of 36 Ineben is watally avealy diatributed throbolout the 12 nonthe of the year furbering o diveraified ogrievilure in the ares.

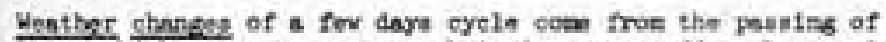
low or hiph pressure centers, bringing scos sudden changes in teserature, mueldity, cloudinese asd vinds. In general, the hifi's bring lover temperaturns, lover heridty and grester sunnhine. An aproeching low sccoupenien a rine in terperntiure, vind, middity and eocreneezat of rain. This aetivity is of

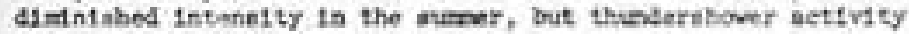
focreanen beglning in the apring.

Wabaib fo fortunste in generally having an evea diatribution of meolplistiog throudost the yenr, a hapry entrast to areat that have a "dry season". The table of monthly ratsfoll for the pest years on the back olde of this report given an Indieation of the variation in ratafnll taht any be expected. The agr-

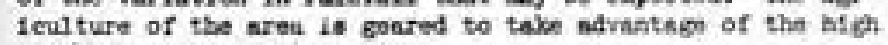
prothibility of regular ratns.

Mny days of the yenr tave pleasent tyseraturnes but in a aldcontinental area inzee varintion of temperatures in a eenach. asd fron eurmer to vinter aut be expected. In 30 years terdpernviued have renged troe -22 to 109 degrens.

Felative hulafty in not' manured at Wabash bus ellastolus Abowis that the poreentages vary froe the $40^{\circ}$ "il during a typicel sureer afternicos to the $90^{\prime}$ s juat before dava. In the vinter, this range 10 from the $60^{\prime} \mathrm{s}$ to the $90^{\circ} \mathrm{s}$.

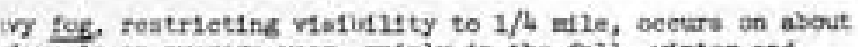
dayn in an arerage yosr, aninly is the fall, vinter and Yyfing wotha. Snovfull averafee about 5 isehes a moth is the vinter. The seascen avernge in il incbes.

Isating degne days in the above table provide a cogserative nus: ber for colctiating basting requireans cs betwen atfrorent plecel and different tires. Puel consumption for hesting in proportional to fegon day totall, wo a moth with twice the bating degres days

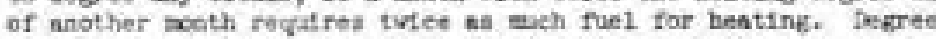
anya for h alngle day sre obtatned by nbtracting the mon teaperatiofe froa 65 decertes.

Mupderitors, includine Incidensee of Hebtaing and thuder, Socur on sbout 42 dayn of the year, according to the elimtologe of the ares. The svoragn is about $8 \mathrm{n}$ minth in the late aprine and early sumer, and leso thas one a zenth th the vister. Itre thunderstorm are seldoe so severe ab to calase loes of life, property, or erope. Daxuge to property fron theth voloctsy atrnight vinde genersted by thinderstorm il most apt to oceur in the spring aonthi. Only 6 tompdose sro en rocord as baving toriched thin corsty.

Uinde blow mot fregunat1y free the nouttwest, hovever in one or two of the winter mothn the jrevalling vinda wre oftes aorthverterly. Som freezies rain or freezing drizzle is expected. about B dayn a yesr, necofiting to a atudy epenaling 1939 througd 1948 .

The groving oestion (doflned here an the muber of daye between the Int sping whd first fill temeraturs of 32 degreen) averegen 160 days in langth. Dhe vennon is $18 \mathrm{t}$ dens or more is 103 of the yeare, 171 anye of mort in 254 of the yesm, less than 149 dayn is $25 \%$ of the yearn, and lesa than 139 deyt is 104 of the gears.

The sun ahines throuptout the year about 575 of the disyl1ght hours. This percentage resert fros los in the vinter to more than

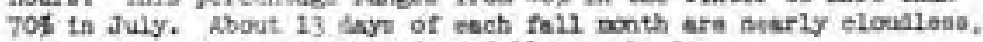
sbout 7 enys are pertily eloubly and 11 are cloady.

The Wabesh ilver occastonsily noods adjseent lov lasts. The prestent river ace located on atate hoed 15 Itideo vould kave reoorded the flve hletat vater arka ha followst 28.7 feet (horch

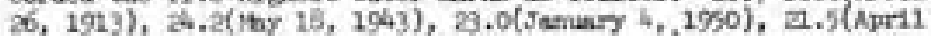
6,1957 ), and 2.1 (Wroh 13, 1959). Toe ando of the river eage 10 642.66 test sbove man sea level.

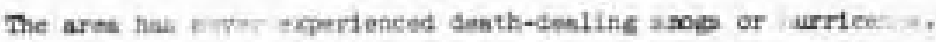

teurenee h. Schasl

Wisther Bureau state Climstologist

Purdian Datveratty, Agrobary Departant tefnyette, Indtane 
Miami County is located in north-central Indiana in the Eastern Lake and Till plains sections of the Central Lowland province of the Interior plaine division of the United States (Fenneman). Two physiographic regions of Indiana (Malott) are represented within its boundaries. The section of the county south of the wabash River is a part of the Tipton Till Plain, and the area to the north is the Steuben Mrainal Lake Section (Malott) and is part of the Northern Moraine and Lake region. An area of typical till plain between the Wabash and Eel Rivers in Miami County should be included in the Tipton Till plain region. It has the physiographic characteristics of the till plain farther south and undoubtedly was formed under similar conditions (1).

Figure 4 shows a topographic map of Miami County and Figure 5 shows a schematic sketch of the physiography of the county. The primary land forms in the county are the: (1) Packerton ridge moraine in the north, (2) Eel River Valley flood plain and terraces, (3) ground moraines- the most extensive land form,(4) Union City ridge moraine, and (5) the Wabash River Valley flood plain and terraces. The newly formed Mississinewa Reservoir has covered slightly over one square mile of ground moraine.

The Wabash River Valley is the lowest area in the county. The river enters the county on the east side at an elevation of 634 feet and leaves the county on the west side at 610 feet. The valley ranges from about a mile and a half wide, to about two miles wide. The river lies both on bedrock and glacial drift. The river has eroded a valley 90 feet below the surrounding upland and local dissection has produced an area of rolling hills for one to two miles on each side of the valley.

The valley has three levels. The lowest level is the flood plain; 15 to 20 feet above this is a terrace, and 20 to 25 feet above this terrace is another terrace. Rock mounds (the ancient reefs), some hundreds to several thousands of feet in diameter, and some several feet to several tens of feet high, are scattered through the valley mainly on the lower levels.

The Mississinewa River, before construction of the dam, entered the county, on the east, at an elevation of 675 and joins the wabash 


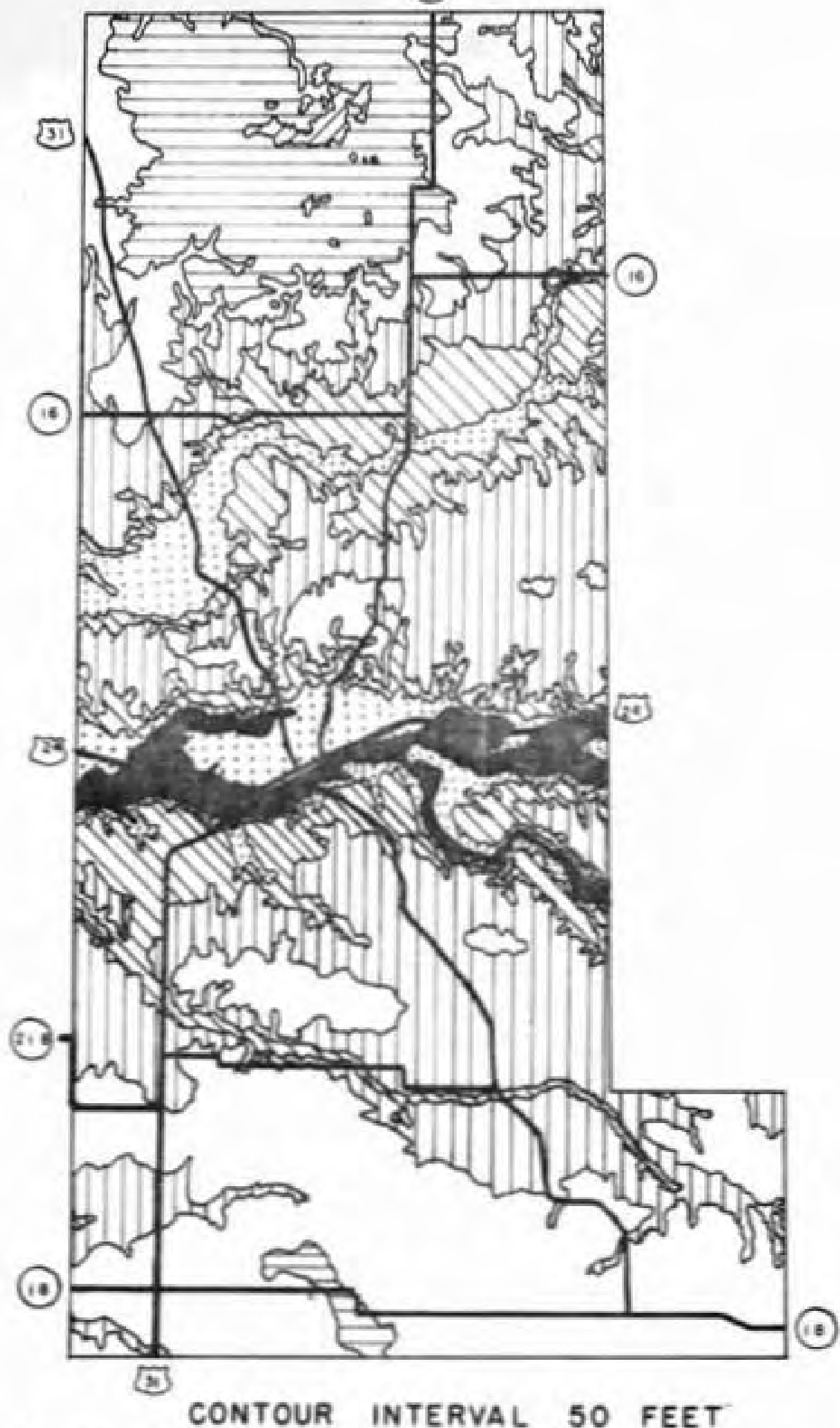

KEY
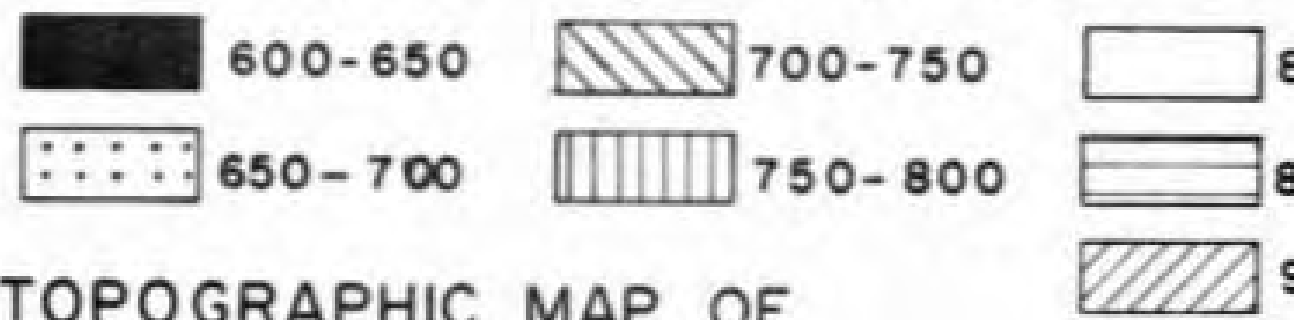

$800-850$ $\because:: 650-700 \quad \square\|\|] 750-800$ $850-900$

FIG.4: TOPOGRAPHIC MAP OF 900- 950 MIAMI CO. 


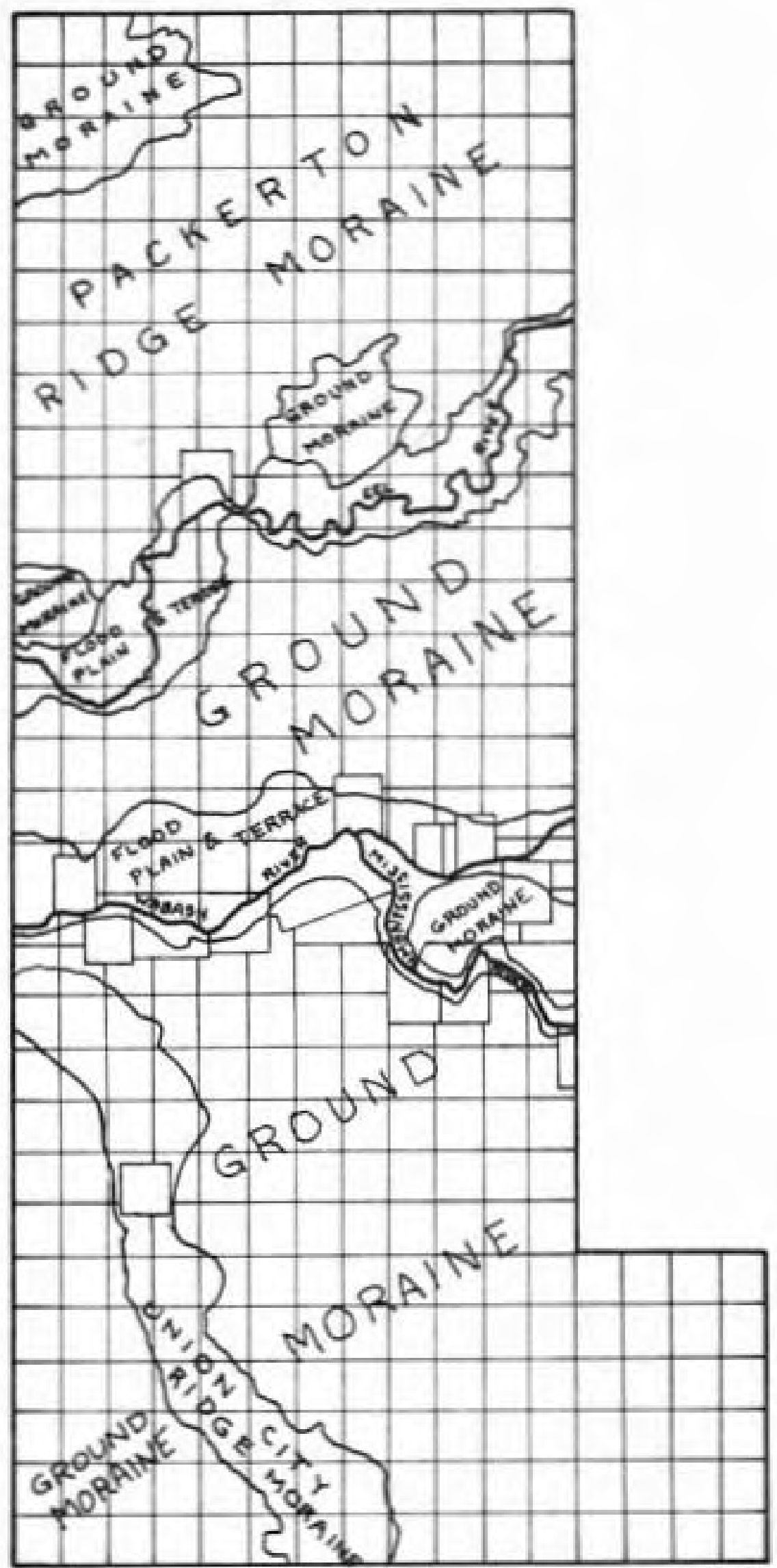

FIG.5. PHYSIOGRAPHIC SKETCH OF MIAMI COUNTY 
at an elevation of 633 feet - a 42-foot drop in eight miles. Below the dam, the valley lies in a narrow gorge cut partly in bedrock. The east side of the valley is cut in bedrock and the west side in un consolidated till to a point about one mile south of its junction with the Wabash where it begins to flow on glacial drift.

The Eel River Valley, crossing the northern part of the county shows considerable contrast to the Wabash River Valley. The Eel Valley is considerably wider, shallower, and has much flatter terrace and valley-wall slopes; there is no exposed bedrock along the valley. Terrace levels are very indistinct and undoubtedly much of the outer edge of the valley outwash material could better be described as outwash plain parent material. The outwash terrace material is correlated with the upper level terrace material of the Wabash Valley. Since the Eel Valley was a sluiceway for both the Packerton and Mississinewa moraines it developed considerable width so that the present Eel River (and flood plain) is an under-fit (undersized) stream for the containing valley. The river enters the county at an elevation of 710 feet and leaves it at an elevation of 649 feet.

The extensive area of till plain (ground moraine) south of the Wabash River has a very gently undulating surface -- it is about the flattest ground moraine in Indiana. The general elevation of the plain is about 800 feet. The till plain between the Eel and Wabash Rivers (average elevation about 780 feet) is gently rolling and the relief somewhat greater than the larger area south of the Wabash River.

The north-south trending Union City ridge moraine has an average width of slightly over one mile and the maximum local relief of the moraine above the till plain is 30 feet. "A somewhat arbitrary altitude of 820 feet was used to delimit its outer edge. The Union City moraine is poorly developed and only locally has the typical characteristics of a terminal moraine. In Miami County, it consists of smooth or gently undulating knolls and is comparatively free of sharp hills". 
The Packerton ridge moraine has a hummocky topography and a few small kames, eskers, sand dunes, lakes and swamps. In some places local relief is over 100 feet and the maximum elevation is about 930 feet. The northwestern half of the ridge moraine, which is quite sandy and mainly has internal drainage, is more hummocky and has considerably more muck and peat basins than the southeastern half of the Packerton ridge moraine.

\section{ENGINEERING SOIL AREAS}

The soils of Miami County can be divided into three major groups: (1) glacial or ice-contact deposits, (2) glaciofluvial, fluvial or water-deposited materials and (3) miscellaneous deposits. In the discussion that follows each of the major groups is further subdivided into land form-parent material groups. These groups are then subdivided into soil textural groups.

\section{GLACIAL DEPOSITED MATERIALS}

The land forms of glacial, or ice-contact deposits in Miami County include ground moraines, ridge moraines, kames and eskers. The location and approximate size of most land forms is shown on the physiographic sketch (Fig. 5) and on the engineering soils maps and so these factors are not discussed below. 
Sandy Surfaced Silty Clay Ridge Moraine

Most of the northern half of the packerton ridge moraine (northern third of the county) is more sandy then the southern half - at least the surface soils. The southern half, and primarily the surface soils, appear to be more silty. Ice, or water, or wind, or some combination of the three, deposited sands and silts, probably originally from the Kankakee basin, over a silty clay soil. The more sandy north is distinguished from the more silty south by different drainage patterns. In the north, drainage is mainly internal. However, because of a high water table open ditches are also used to promote drainage. The silty southern half (with some sandy areas) has a somewhat more developed surface drainage system.

"The till in the area of the Packerton moraine is much more sandy than that in the area south of it. Associated with the sandy till are many areas of well-sorted sand. The sand, which ranges from one foot to 20 feet in thickness, is yellowish brown, unstratified, round to subrounded, fineto medium-grained, well sorted, and, in many places, contains a few pebbles.

"The origin of these sand deposits is debatable. Some of the deposits appear to have been reworked and deposited by wind. On the whole, however, they do not have the topagraphic form of dunes. Clay and boulders are so scarce in the sand deposits that they could be described correctly as sandy till. Perh aps the most logical interpretation is that they represent sand dumps which were made by water in, beneath, or against the ice. Evidence of stratification, however, rarely can be found. Because of the uncertainty as to the exact origin of these sands, ... they are mapped as undifferentiated sands". (1)

On the attached engineering soils map these sand areas are shown as dune sands - rather than sand dunes. A few true sand dunes are found on the Packerton ridge moraine but most of the true sand dunes of the county are found in Eel and Wabash Valleys the latter are discussed later.

The sandy northern half of the Packerton moraine also contains numerous large muck deposits. There are several areas containing some gravel, which in turn, contain a few small kames and eskers. All these areas are discussed under specific headings in the following pages. 
The main soil mass area of the sandy textured portion of the Packerton ridge moraine (other than the dune sand areas) has a general profile as follows. The topsoil ranges from a fine sandy loam to sand. The subsoil is sandy loam or sand. The unweathered material varies from a clay loam to a sandy loam. The soil profile in the low areas show a finer texture. The surface soil varies from a sandy loam to organic loam. Sandy loam, sandy clay loam or clay loam is found in the B-horizon. The parent material ranges from clay to clay loam.

Soils on the western side of the Packerton moraine in Miami County are similar to soils on the western side in Kosciusko County where they were sampled and tested. The following soil test data is for three test sites about ten miles north of the Miami-Kosciusko line. These three sites are in areas where the sand deposits are shallow and the parent material is predominantly fine grained. A fourth sample, described below penetrated a thick sand deposit.

"The typical soil sample was taken at site No. 23 located about one mile east of Claypool. The surface soils or topsoils (A-horizon) are about 12 inches in thickness. It is a loose sandy soil with little organic matter. Small stones and gravel are usually present. The B-horizon taken between 12 and 24 inches from the surface contains 5.08 gravel, 64.78 sand and 30.38 fines. It has a liquid limit (LL) of 13.68 but is non-plastic. The C-horizon taken from 2 to 3 feet below the surface reveals 5.78 gravel, 24.48 sand and 69.08 fines. The LL indicates an increase to 21.38 and a plastic index (PI) of 7.78 . The silty sand B-horizon has a stronger supporting power than the till C-horizon. It shows a CBR value of 15.0 while the C-horizon shows only 3.7 . The subsoil (B-horizon) is classified as $S M$ and $A-2-4$ by the USCS (Unified Soll Classification System) and BPR (Bureau of Public Roads) classification respectively. $C L$ or $A-4$ (7) soil is the elassification of the parent material of the area.

"Another soil sample taken at site No. 24 about three and a half miles directly south of the previous site shows essentially the same parent material. However, the B-horizon is much less sandy than that of site No. 23 . It has 3.98 gravel, 43.78 sand and 52.48 fines. The LL and PI are 25.8 \% and $8.8 \%$ respectively. It is classified as CL or A-4 (3) soil.

"Test site No. 3 is located west of Claypool in a depression. The water table was about 2 feet from the surface during the summer months. The B-horizon sample was taken at 3 feet from the surface. The dark colored soil shows 8.28 of gravel, 37.58 of sand and 54.38 of fines. It has a LL of 28.98 and a PI of 11.98 and is classified as CL or A-6 (4) soil. The parent material samples at 5 feet from the ground 
surface indicates more sand and less plasticity. It is be-

lieved to be the same as those at site No. $23^{\prime \prime}$. (10)

Pedologically most of these soils appear to belong to the Miami, Crosby and Brookston catena and additional engineering soils data are shown on Table 1.

The following data is from a test site in adjacent Cass County. The site is about two miles west of the Cass-Miami County line and was in one of the deeper sand deposits.

"In the extreme northeastern corner of the county, the Packerton Moraine is rolling and hummocky. The surface materials include deposits of sand and pebbles, somewhat modified by wind action, interspersed with extensive areas of organic muck and peat. Distribution of the sands is somewhat irregular, and knolls of clean sand alternate randomly with those of sandy silts. The principal soil of this area is designated as Coloma sand by the agricultural soil survey.

"Test site No. 11 is located in this area. It is chiefly sandy in texture throughout the soil profile. A fine silty sand A-horizon is about 8 inches in depth. The non-plastic B-horizon has 69.28 of sand, 29.48 of fines and only 1.48 considered as gravel. Sand increases to 938 and fines decreases to 7.08 in the non-plastic c-horizon. Both the subsoil and the parent material are strong in load bearing capacity. They have CBR values of 20.0 and $21.8 \mathrm{re}-$ spectively. The subsoil is classified as SM and $A-2-4$ soil by the USCS and the BPR classification while the parent material is evaluated as poorly graded sand with silt (SP-SM) and fine sand $(A-3)$ by the USCS and BPR specification." (11) 


\section{Silty Surfaced Silty Clay Ridge Moraine}

The southern half of the Packerton Ridge Moraine has a silty (sandy in some areas) cover a few inches thick to several feet thick. The basic underlying parent material, however, is a silty clay. In general, the sand content decreases to the south and the thickness of the sandy silt blanket also decreases to the south. Exceptions occur adjacent to the rivers where thickness of the silt and sands occasionaliy increase.

Overall, the general blanket thickness is enough to influence the surface drainage. In some areas, the drainage is mainly internal indicating an area of more sand than silt but most of the general area shows a combination of sheet wash and internal drainage indicating a sandy silt blanket over a silty clay soil.

The soil texture of this area is somewhat less sandy and more silty than that of the sandy textured area. The surface soil is loam or sandy loam in the high topagraphic positions. The subsoil ranges from a clay loam to a sandy clay loam and the parent material varies from clay loam to sandy clay loam. In the low areas the surface soils vary from loam to silty clay loam - occasionally organic. The subsoil ranges from silty clay to clay and the parent material from clay loam to clay. Clayey Ridge Moraine and Ground Moraine

The Union City ridge moraine, extending northwest-southeast across the southwest corner of the county, is a very low, poorly developed and poorly defined ridge moraine. The eity of Bunker Hill lies on the Union City ridge moraine. Ground moraine, with the same parent material as that of the ridge moraine, covers most of the southern $2 / 3$ of the county - see Figure 5 .

The parent material of this ridge and ground moraine is a moderately plastic to highly plastic clay (derived from shales and limestones) mainly from former glacial lakes in the northern part of Indiana and ohio. Clay content of the parent material ranges from about 35 to 55 percent, whereas clay contents of tills west of the Union City ridge moraine range from about 30 to 40 percent.

Most always the clay component in each soil horizon predominates but occasionally one or the other of the horizons is found to be 
silty. Most soils classify as clays or clay loams. The clayey layers are either moderately plastic clays or highly plastic clays. Many of these clays (A-7 clays) are also elastic. The clays are elastic for any one or all three of the following reasons: (1) the presence of one-size silt particles, (2) organic matter or (3) lime carbonate.

Pedologically the clayey soils are Blount, Morley and Pewamo. Though no samples were taken for engineering soil tests in Miami County, engineering test data for these soil series, sampled in Allen and Delaware Counties, appears in the back of this report.

\section{Silty Granular Ridge Moraine, Kames and Eskers}

In the Packerton ridge moraine there are several areas, possibly up to several hundreds of acres, that may be somewhat gravelly. The areas have a slightly knobby appearance and also appear to have considerable internal drainage. Undoubtedly most of these granular areas contain more sand than gravel and are quite dirty with silt.

The granular portions of the ridge moraine and the kames and eskers most likely acquired their materials from the same source area. The kames and eskers should be somewhat better sorted and stratified and somewhat cleaner than the granular ridge moraine areas. However, on the soil map, the same profile is used for the granular ridge moraine, kames and eskers.

There are several kames in the northwestern and northeastern corners of the county. They are all small and inconspicious. On the soils map, the kame and esker areas indicated are areas containing a number of small kames and eskers rather than one large kame or esker.

A few of these land forms that have been opened for sand and gravel, show: (1) more sand than gravel, (2) gravel sizes mainly under one inch, (3) and an overall silt content of about 5 to 25 percent. Pits in kames and eskers appear to be used only locally by individuals.

In the high position (granular ridge moraine, kames and eskers), a loamy or fine sandy loam surface soil is commonly found. Due to severe erosion, the surface soil may be entirely removed on steep 
slopes. The subsurface of a sandy texture is underlain by a gravelly, sandy clay loam subsoil. A stratified gravel and sand is generally found in the parent material However a loamy textured soil may occur.

In the low position, surface soils are loams and silt loams. The subsurface soil varies from a silt loam to a silty clay loam. The parent material is clay loam.

\section{Sandy Surfaced Silty Clay Ground Moraine}

In the northwest corner of the county, is a small area of sandy surfaced ground moraine. The soil profile is similar to that of the sandy surfaced ridge moraine except that the A-horizon is thicker and a little more loamy in texture. In the low topagraphic area the textures of the upper layer are more silty and clayey than that of the ridge moraine. The surface soil varies from a loam to an organic silt loam. The subsoil ranges from clay loam to silty clay. The parent material is clay loam or clay.

\section{Silty Surfaced Silty Clay Ground Moraine}

In the northwest corner of the county, is a small area of silty surfaced silty clay ground moraine. The soil texture is essentially the same as the corresponding ridge moraine material. However, because of the less erosional effect of the subdued topagraphy in the ground moraine, the A-horizon is thicker than that of the ridge moraine. The parent material contains more clay than that of the ridge moraine.

\section{Silty Clay Ground Moraine}

The ground moraine west of the Union City ridge moraine and also that between the Wabash and Eel Rivers was probably formed from an ice lobe carrying a loam textured soil of a more mixed origin than the more clayey soils to the east. This ground moraine, in the southwestern corner of the county and between the two large rivers, has a parent material of Miami, Crosby, Brookston, Russell and Fincastle soils.

Soils, of the same parent material, were sampled and tested from adjacent Cass County -- borders Miami County on the west. The following discussion of soil testing for Cass County is also appropriate for Miami County. 
tiquid limit and plastic index values of 20-25 and 6-12 respectively are reported as average values for the c-horizons of Tipton Till Plain by Belcher, Greeg and Woods (9); these values are confirmed by tests, (site No. 1 and No. 2) in connection with this investigation. Somewhat higher values of $\mathrm{LL}$ and PI occur in the B-horizon, which extends to depths averaging three to four feet.

"The typical soil profile is found at test site No. 2. The silty A-horizon is about 6 inches thick. The B-horizon contains 13.98 sand and 84.68 silt and clay. It has a LL of 36.88 , a PI of 19.98 and a CBR value of 10.0. It is classified as CL and $A-6$ (16) soil by the USCS and BPR system respectively. In the C-horizon, with sand increased to 49.78 and the fines reduced to 46.48 , the LL and the PI are both reduced to 23.08 and 8.08 respectively. However, the CBR value only changes slightly to a value of 8.9. This parent material is designated as SC and A-4 (2) soil by the above mentioned systems.

"A fact of interest is the occurrence of windblown silt mantle overlying the glacial material immediately adjacent to the Wabash valley. At test site No. 1 the light uniformly textured silt extended to a depth of about two feet below which a weathered B-horizon was encountered in the underlying till. The silt mantle thins rapidly and disappears within about a mile south of the river, which is likewise the approximate extent of gully penetration into the upland. A distinction should be recognized between windblown silt, or "loess", and the sandy silts of glacial origin which forms the soil-parent materials of most of the fine-textured soils discussed herein.

"Below the 6-inch silty top soil, the upper B-horizon taken between a depth of 6 to 24 inches, reveals the following data: 3.7 \% grave1, 21.58 sand, 74.88 fines, LL of 29.18 , PI of 12.18 and a $C B R$ value of 4.9 . The $B_{2}$-horizon taken from 24 inches to 60 inches, which is the weathered zone of the till, shows an increase of sand $(41.88)$, decrease of fines $(55.88)$ and a slight increase of LL (33.58) and PI (14.48) and a CBR value of 4.9. These B-horizon soils are essentially classified the same (CL by USCS and A- 6 by BPR). The C-horizon taken below 60 inches indicates almost the same in grain size distribution but a slightly lower LL (27.98) and PI 
(10.78) than that of the $\mathrm{B}_{2}$-horizon. However, the bearing capacity increases to a CBR value of 6.7 . The parent soil is classified about the same as the B-horizon by the adopted systems." (11).

\section{FLUVIAL DEPOSITED MATERIALS}

The fluvial deposited materials of Miami County are tabulated below according to their land form and parent material texture. Rock benches, though not fluvial deposits, form terraces along with sand and gravel terraces in the same stream vally and so are listed here.

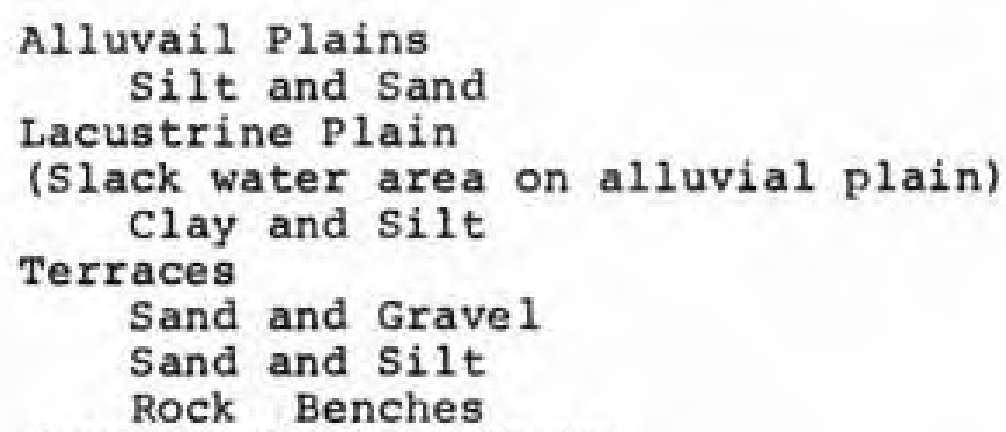

(1) Alluvial Plains - Silty and Sandy

Both the Wabash and Eel valleys average about one and a half miles in width but this is about their only similarity. The Wabash valley, except for two large terrace areas in the western half, is essentially flood plain over its entire width. In contrast the Eel River valley has a very narrow flood plain (averaging several hundred feet in width) and most of its width is terrace. The Wabash River has cut into bedrock in many places while the Eel River lies entirely in glacial drift.

In east-central Miami County, the Mississinewa River enters the county and flows for several miles, mainly on rock, before joining the Wabash River. A dam, built by the U.S. Army Corps of Engineers, produced the Mississinewa Reservoir, part of which is in Miami County but most of which is in adjoining Wabash County. Boundary lines for the reservoir flood control pool are shown on the attached engineering 
soils maps. The flood plain of the lower part of the Mississinewa River averages about one half mile in width.

Three creeks in the southern half of the county with fairly well developed flood plains include: Pipe Creek, and (3) Deer Creek.

(1) Big Pipe Creek, (2) Little

The flood plains are land forms that were constructed after glaciation. Precipitation and erosion have removed clays, silts and sands from the surrounding upland and flood waters redeposited these material on the bottom lands along side the streams.

Pedologically the flood plain soils are Genessee, Eel, Shoals and sloan - engineering soils data are provided in

Table I.

(2) Lacustrine Plain (Alluvial Plain Slack Water Area) - Clay and Silt Texture

In Wabash County, to the east, where the Wabash River came out of a bedrock channel onto unconsolidated glacial drift (preglacial Teays valley) it abruptly cut a very wide channel. The widened channel in Miami County is on the Miami-Wabash County line. The widened channel later caused a slack water lake where considerable clay and silt were deposited. Several drainage ditches have been cut through the area to promote drainage.

"This area, formerly known as 'the Prairie'

has a black (organic) crumbly silty clay and clay surface soil which changes with depth to lightercolored clay, in most places underlain by sandy

or gravelly material at a depth ranging from 50 to

60 in. from the surface." (7)

Engineering properties of the Abington (possibly Toledo) slack water soils are found in Table I.

(3) Terraces - Silty, Gravelly Sand

Miami County has many square miles of terrace area along the Ee1, Wabash and Mississinewa Rivers and also along a number of smaller streams. It is unfortunate that most of the granular material underlying these terraces is primarily sand and in some cases bedrock. Where there are thick deposits of granular material it is usually assorted into numerous thin to thick layers of sand and much fewer and thinner layers (or lenses) of gravel. Most of the gravel is also of the smaller sizes. 
In general, it appears that most of the deposits over the county can be classified as silty gravelly sand. Under the next heading several locations are given where the granular material may be more gravelly - as interpreted from the airphotos. The following two paragraphs by Wayne and Thornbury are quoted to provide information on aggregate mineral composition and distribution.

"The most extensive valley train in the region is along the Eel River and consists of rounded and well assorted outwash gravels. Most of the pebbles are limestone and dolomite, but some shale is present. The overburden is thin and consists of weathered gravel and sand. Due to a relatively high water table, some of the pits in this area are wet operations.

"Gravel deposits are found in the bluffs along the Wabash River where it crosses buried sluiceways, but a thick till overburden has prevented extensive exploitation." (1)

Pedologically the soils are mainly Martinsville, Westland and oshtemo. Engineering soils data are provided in Table I. (4) Terraces - Sand and Gravel Texture

Several terrace areas appear that they might be more gravelly than the greater majority of terrace deposits - described above. However, it is doubtful if the amount of gravel exceeds the amount of sand by a significant percentage even in these so-called more gravelly areas.

The two large terraces in the Wabash valley west of Peru appear to have a higher percentage of gravel. In the Eel River valley, areas around Mexico and Pettysville and several smaller areas between these towns appear more gravelly. Also included in this group are small terraces along the Mississinewa River and the western area of Pipe Creek.

The "1968 Directory of Sand and Gravel Producers in Indiana" lists only one significant sand and gravel producer in Miami County. It is the Kickapoo Sand and Gravel Corporation at Catholic Cemetery Road (southwest of the Peru City limits). The pit is owned by the J. C. O'Connor Company and produces 2,000 tons per day of processed sand and gravel. 
The following information on sand and gravel resources in the county is quoted from, "The Geology of Miami County", dated 1955 (1), [At the time of this writing, July 1972, some of this data may be out of date.]

"Sand and gravel are obtained from terraces along the Wabash, Eel and minor sluiceways, from outwash gravels beneath Recent alluvium, from outwash that was buried beneath till, and from kames and eskers. Thick beds of gravel in buried valleys and local lenses of gravel within till provide a large potential water supply.

"The abundance of sand and gravel in Miami County is reflected by the many good gravel roads in the county. About 75 pits, of which 10 are active, or active on demand, and 65 are abandoned, are scattered throughout the county. The sand and gravel are obtained from Tazewell and Cary outwash and from kames and eskers.

"Three sand and gravel pits in Miami County are active. Two large pits are owned by the J. C. O'Connor Company. The large pit that is on the Maumee terrace just west of Peru, in sections 20 and 21, T $27 \mathrm{~N}$., R. $4 \mathrm{E}$, , uses a dragline to load the sand and gravel... About two miles east of Peru, in the SW $1 / 4$ section 19 T27N., R5E., outwash sand and gravels that are buried beneath alluvium are being stripped... The third active pit in Miami County is owned by Riley Behny and is on the Mississinewa terrace south of the Mississinewa River, in the SW $1 / 4$, SE $1 / 4$ section 10 , T26N., R. 5E.... Seven pits have been stockpiled to furnish sand and gravel upon demand. Four of these pits are on the Mississinewa terrace along the Eel valley, one pit on the Mississinewa terrace along the Mississinewa Valley, one pit along the bluffs of the Wabash Valley, and one pit in Tazewell outwash along Big Pipe Creek.

"The sand and gravel are used for surfacing the county roads. The greatest problems encounted in this industry are concerned with the removal of large boulders, the presence of large lenses of sand, and the presence of an overburden too thick to remove economically. At many places in the county, however, gravel can be produced profitably." (1)

(5) Rock Benches

Most of the rock benches are found along the Wabash and Mississinewa Rivers but some are too narrow to show on the engineering 
soils maps. Essentially all of them have one to several feet of overburden mainly clays or silt loams. Reef rock areas are indicated on the attached soils map and have been described in the Bedrock Geology section of this report.

The biggest rock bench area is under the city of Peru and continues westward along the north side of the Wabash River. Several small benches occur along Pipe Creek at the western edge of the county.

(6) Sandy Outwash Plain

The one small outwash plain area lies in the north-central part of the county. It is actually the tail-end of six-mile long outwash area extending northwesterly into Fulton County. As the outwash comes from a very sandy area, it is most likely that the parent material is a silty gravelly sand. Infiltration basins in the plain surface are small and weakly defined on the airphotos.

\section{MISCELLANEOUS MATERIALS}

Sand Dunes - Uniform Fine Sand Texture

Most of the typical sand dunes of Miami County are found in the Eel Valley - mostly in the western half. There are a few dunes on the eastern side of the Wabash Valley and a few small ones in the northern half of the county on the Packerton ridge moraine.

"Sand dunes are abundant on the terraces along the Eel Valley and small areas of wind-blown sand are found along the Wabash Valley, chiefly near the the east edge of the county. The dunes range from indistinct mounds a few feet high to conspicuous dunal mounds as much as 40 feet high. Their average height, however, is about 20 feet high. The sand is mainly well-rounded quartz sand: Cross bedding, although not prominent, is evident in some exposures. The sands were derived from the outwash of the valley trains. As soon as Cary melt water began to diminish, the prevailing westerly and northwesterly winds gathered the dry, loose sand and began the construction of the dunes. Undoubtedly, dune growth continued until vegetation had become established on the surfaces of the valley trains." (1)

In the northern part of the county there are many areas on the engineering soils map shown to be covered with dune sand (rather than sand dunes). The soil profile for these areas is the same as the soil profile indicated for sand dunes. The dune sands are discussed on page 17 . 
The sand dune soils were originally named coloma. They are now called Chelsea. Engineering soil properties of these soils are provided in Table I.

Muck, Peat and Mar1

In the northern part of the county, in the Packerton ridge moraine, there are numerous muck and peat deposits. Most have a high water table.

Though some peat and marl have been mined occasionally in the past, it appears that these deposits in the county are minimal.

"The area in Squirrel Creek near the northeast boundary of the county is underlain by rather pure marl at such slight depth that this material is exposed in the channel. Similar marl occurs in various other places in the county." (2)

"The area about a mile east of Macy includes some coarse brown fibrous peat... The area three miles southwest of Gilead is section 26 is mixed fibrous and woody debris... Many of the areas throughout the northern part of the county afford good pasture, but the average ground water level is too high to render the areas safety tillable..."

"The largest deposit is just north of Peru and was formely called a marsh. It is now well drained and farmed and the average depth of muck and peat is five feet. There are lenses of impure marl. "Limestone is the bas al rock structure."

Pedologically the soils are mainly Carlisle, Rifle, Twas and Linwood muck - engineering soils data is provided in Table $I$. 
1. Thornbury, w.D., and Deane, H.L., "The Geology of Miami County, Indiana," Bulletin No. 8, Indiana Department of Conservation, 1955.

2. Tharp, w.E., and Kunkel, D.R., "Soil Survey of Miami County, Indiana, U.S. Dept. of Agriculture, Bureau of Chemistry in cooperation with the Purdue University Agricultural Experiment Station, Series 1927 Number 24.

3. "General Soils Map -- Area 2, U.S. Dept. of Agriculture, Soil Conservation Service; 65-A E. Second St., Peru, Indiana, 1968.

4. "Population Trends for Indiana Counties, Cities and Towns, 19601970," Highway Extension and Research Project for Indiana Counties, Purdue University, 1971.

5. Yeh, P.T., "Drainage Map of Miami County," Joint Highway Research Project, Purdue University, 1953.

6. "Mississinewa Reservoir, Mississinewa River, Indiana," U.S. Army Corps of Engineers, Louisville, Kentucky, 1966.

7. Wayne, w.J., "Thickness of Drift and Bedrock Physiography of Indiana North of the Wisconsin Glacial Boundary," Indiana Department of Conservation, Geological Survey Report of Progress 7, 1956

8. Schaal, L.A., "Climate of Wabash Indiana," Agronony Department, Purdue University.

9. "Climatological Summary," (Means and Extremes for Period 1933-1962), U.S. Dept. of Commerce, Weather Bureau in Cooperation with City of Wabash.

10. Yeh, P.T., Narain, J., "Airphoto Interpretation of Engineering Soils of Kosciusko County, Indiana," Joint Highway Research Project, Purdue University, June 1960.

11. Yeh, P.T., Becker, R.E., "Airphoto Interpretation of Engineering Soils of Cass County, Indiana," Joint Highway Research Project, Purdue University, November 1959. 


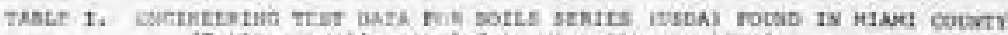
troife actualty raryiled in rieinity pounties?

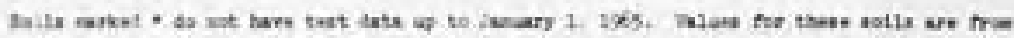

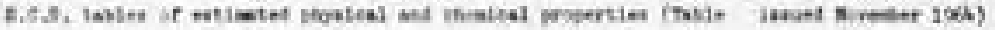

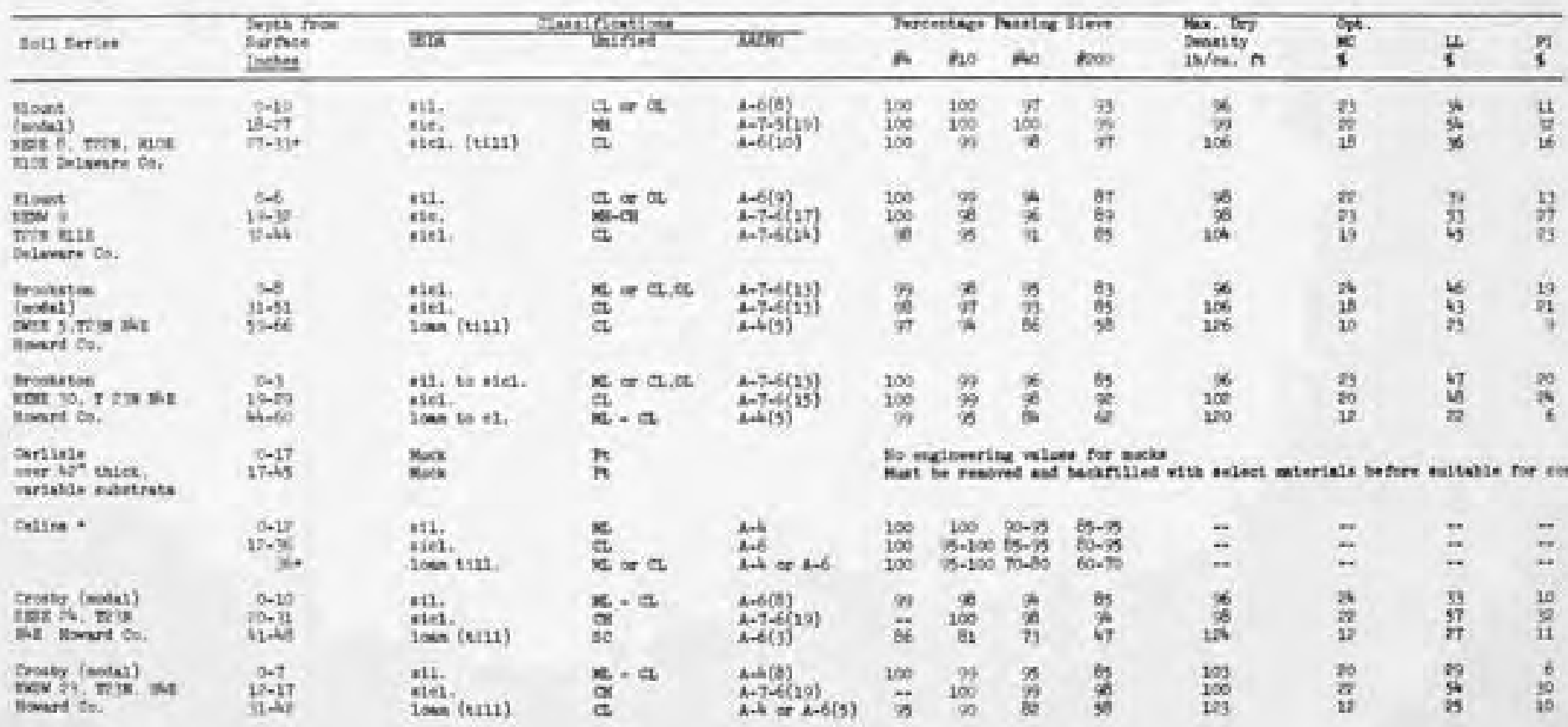




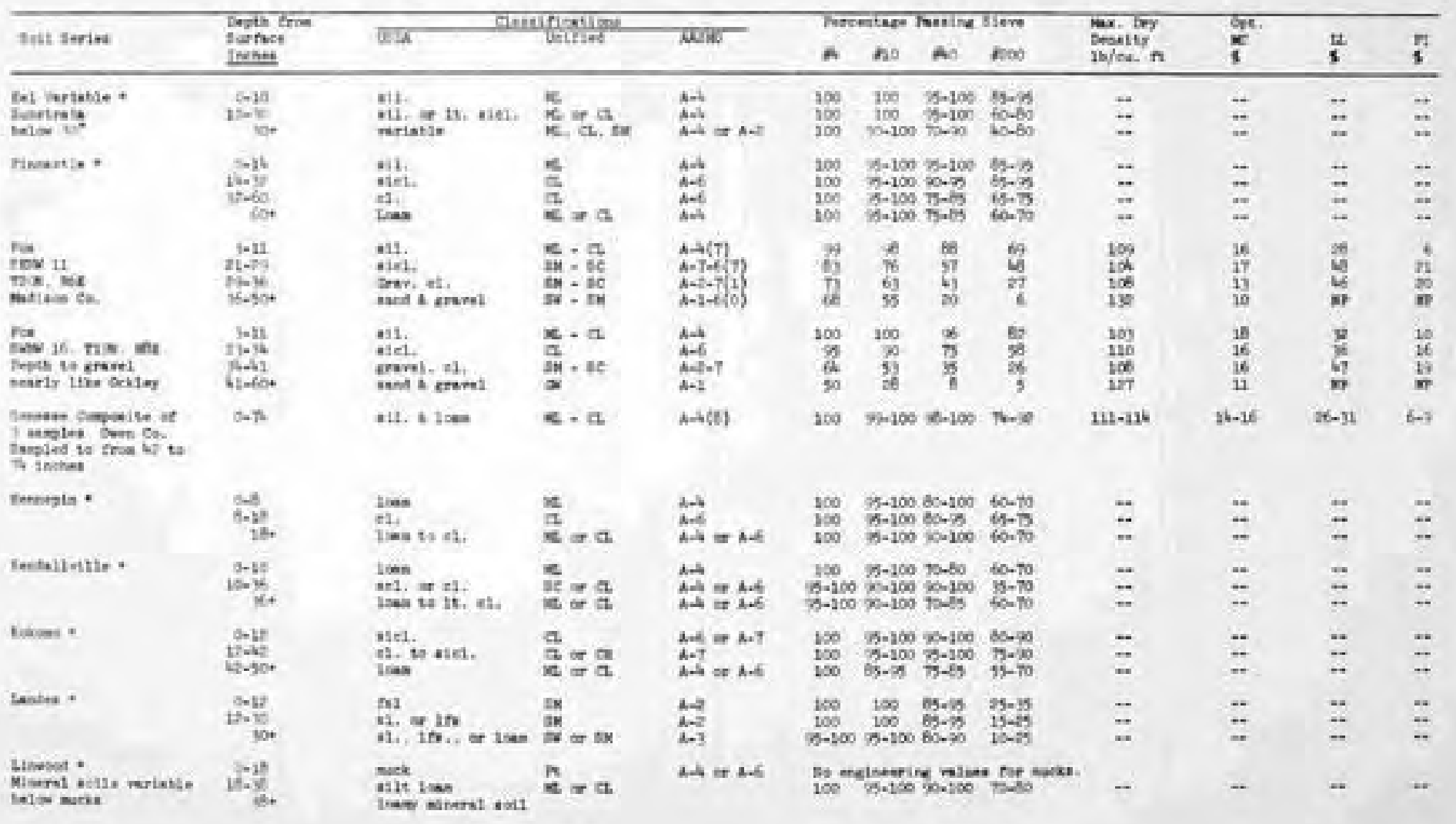




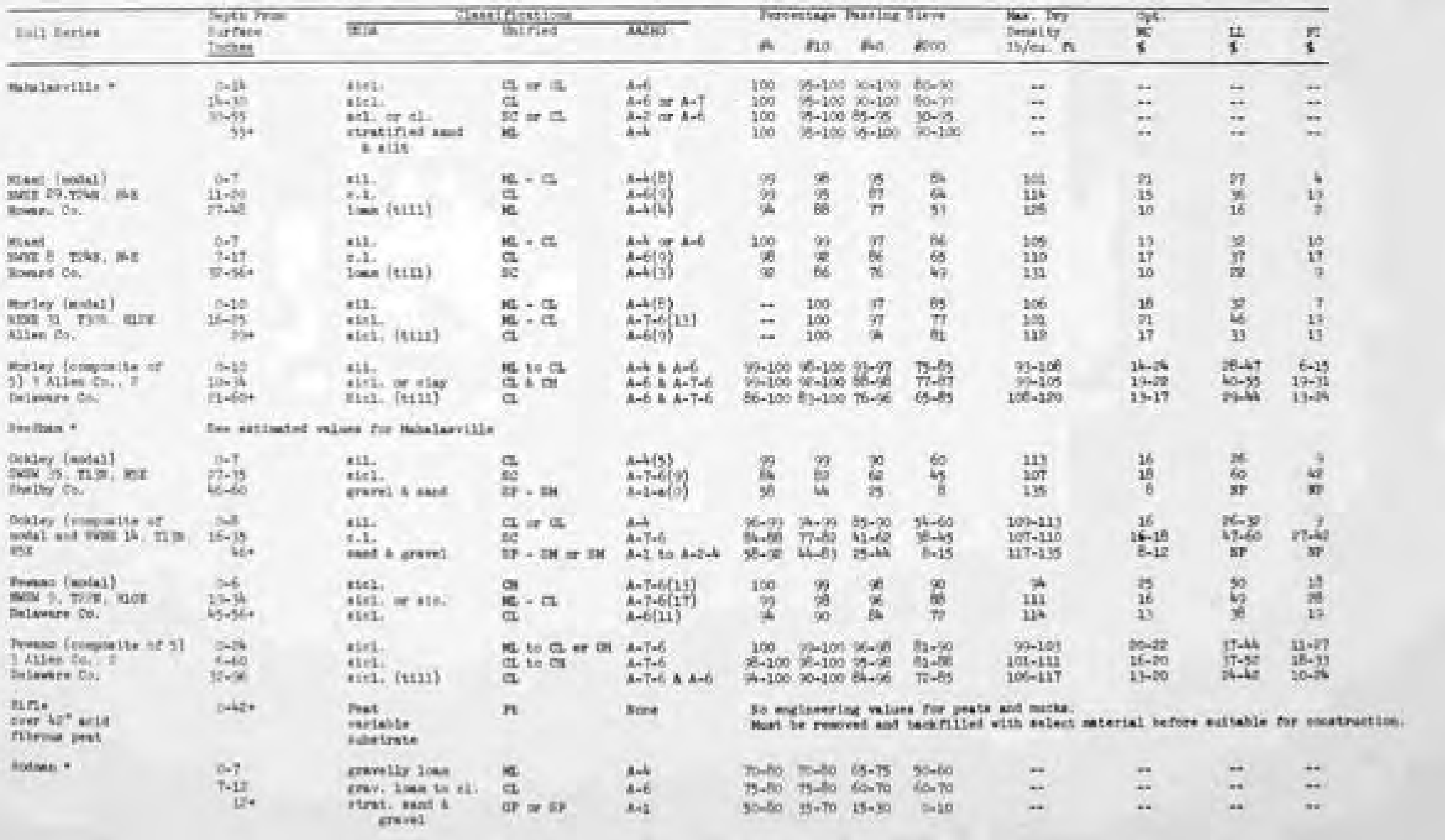




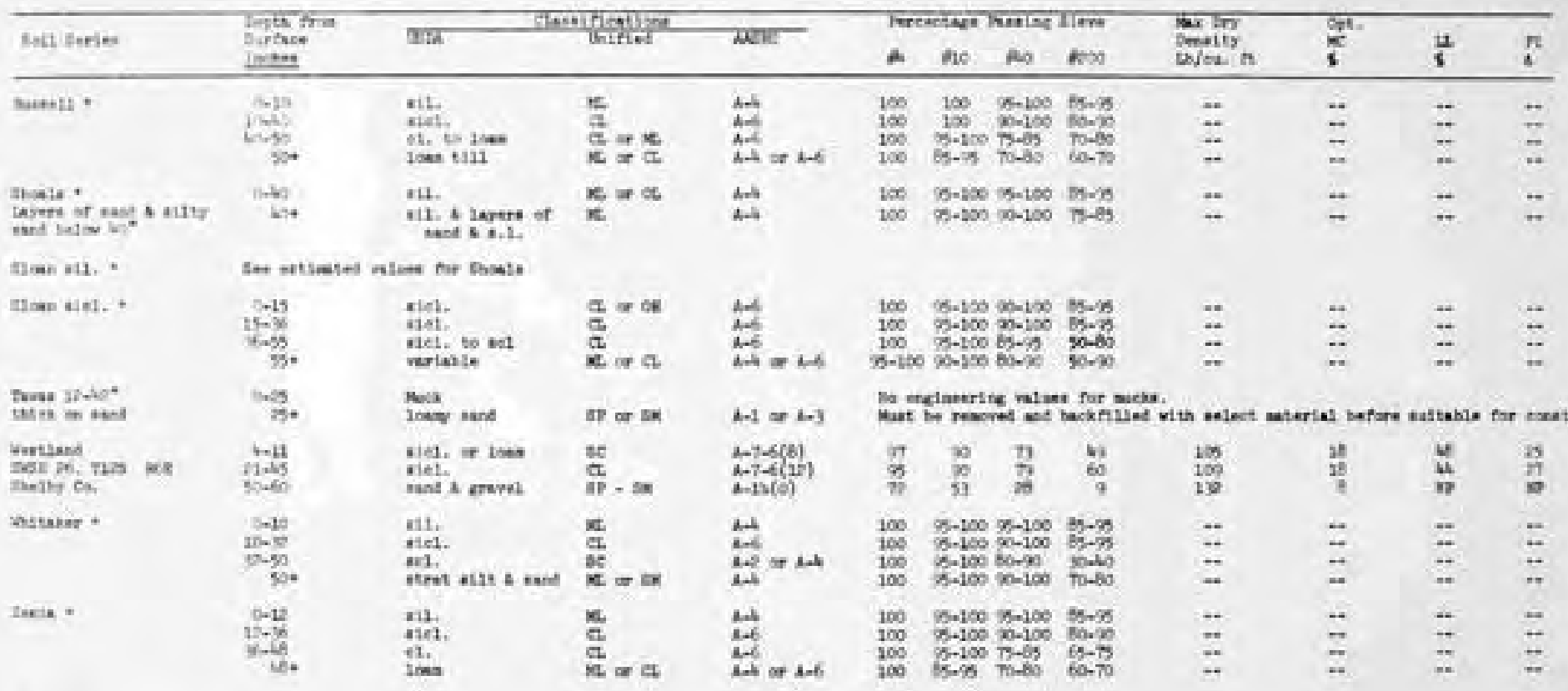




$$
J \text { HRP } 7 2 \longdiv { 3 5 }
$$




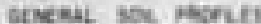

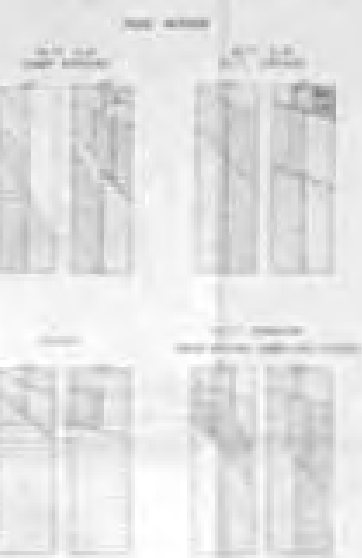

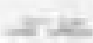<smiles>C1CC1</smiles>

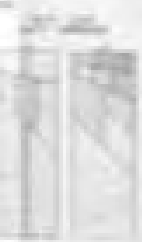

$-$

350.

(1)

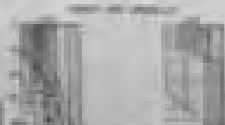

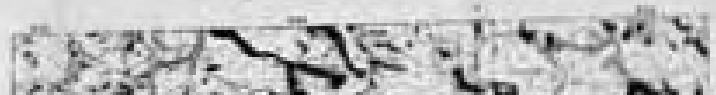

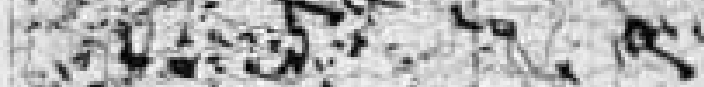

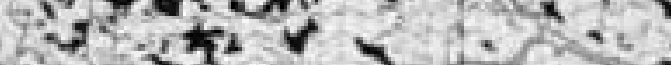
$14^{3}=\frac{x^{2}}{3}+3$ is 24. et:ires?

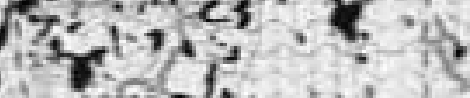

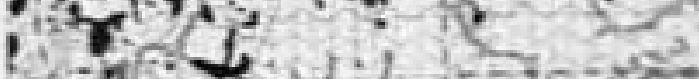

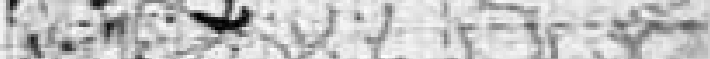

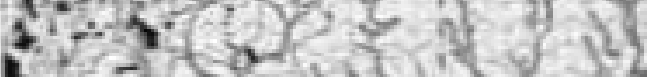

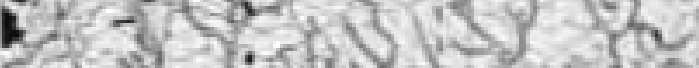

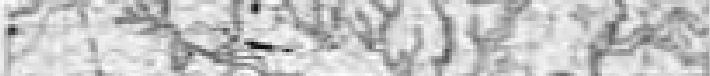

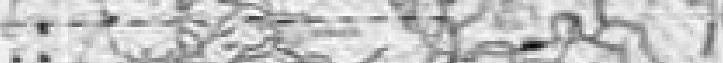
$\because 3+$ a

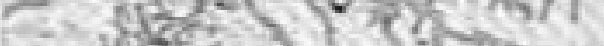

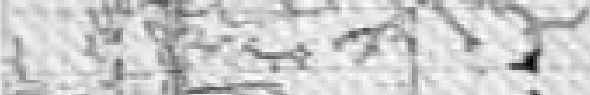
$2=-1+2 \pi$

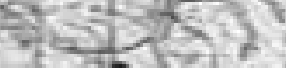

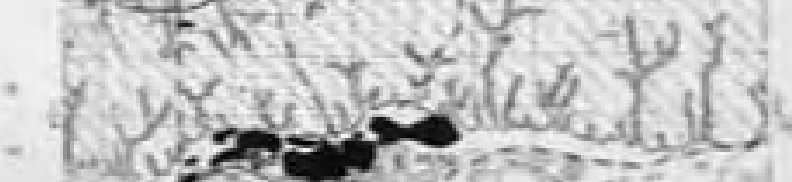

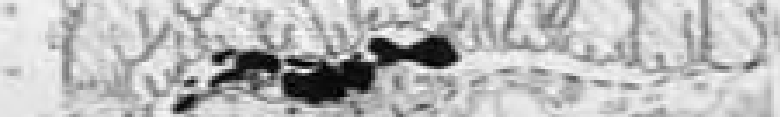

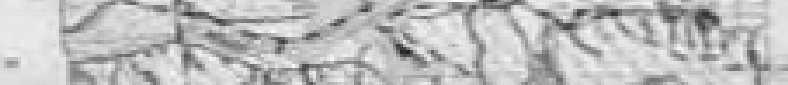
S5)

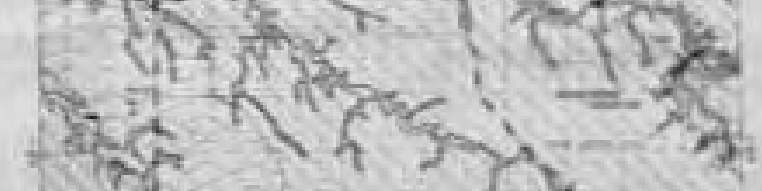

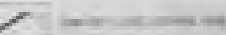
ron $\times-\cdots$
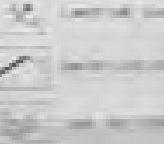

artacions: in

$27+2=0$

$2+\cdots+\cdots$

$+2=$

3

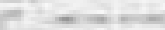

픈 


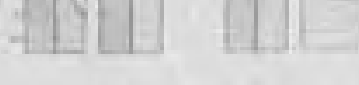

\section{Ext}
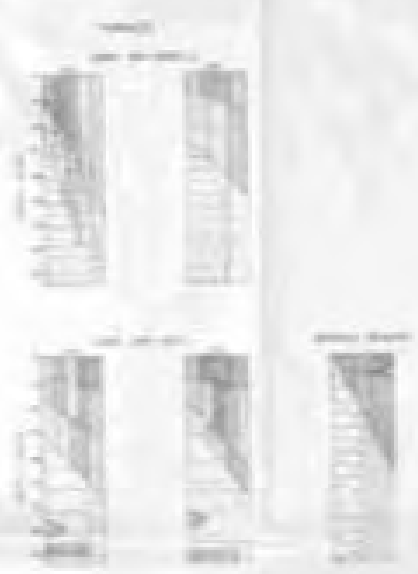

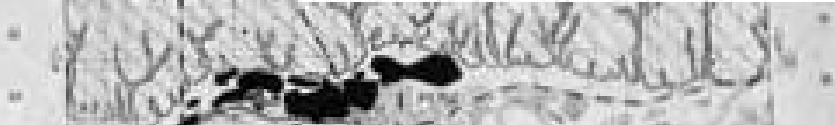

varthastas

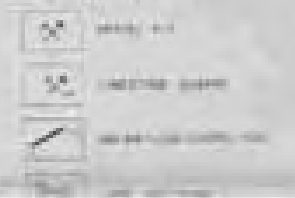

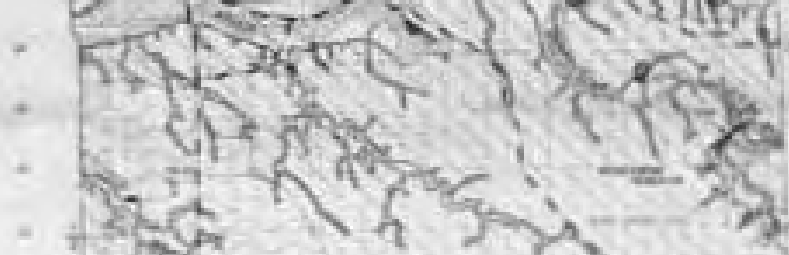

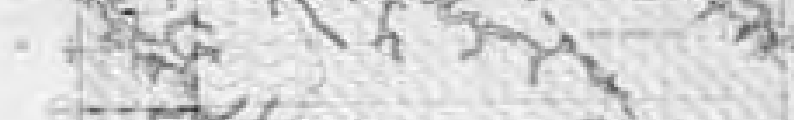
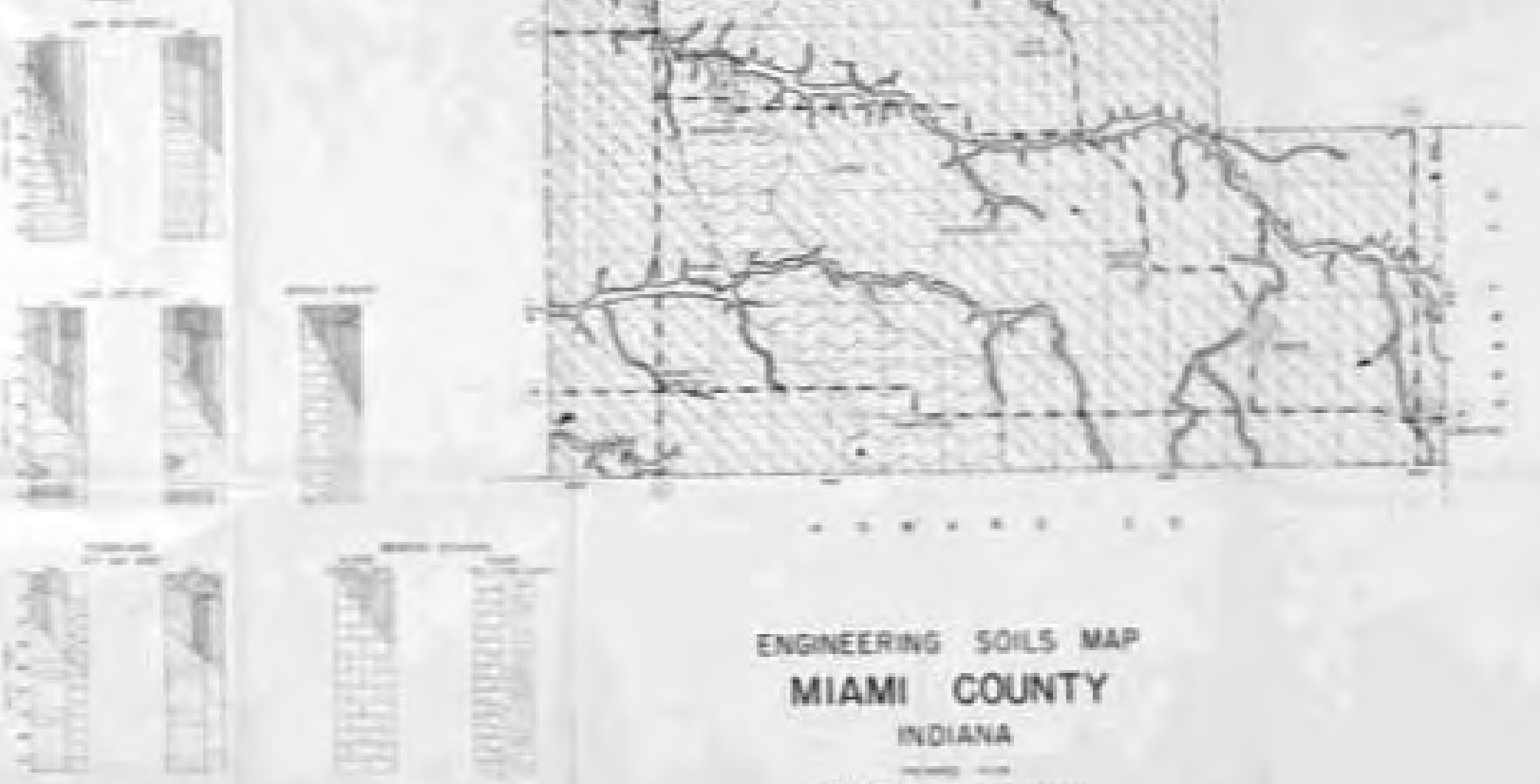

Lis

\section{ENGNEERNS SOILS MAP}

MIAMI COUNTY

\section{indiavia}

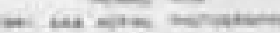

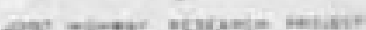

